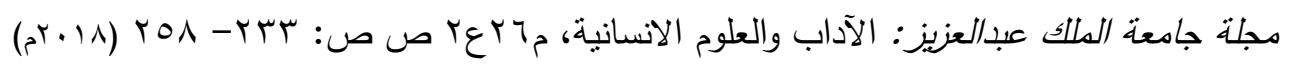

DOI:10.4197 / Art.26-2.10

العلاقة بين أبعاد القيادة التحويلية والإبداع الإداري من وجهة نظر أعضاء هيئة التدريس في جامعة الإمام عبد الرحمن بن فيصل

الاكتورة يمنى أحمد عتوم الإمان

$$
\begin{aligned}
& \text { أستاذ الإدارة التتريوية المساعد، جامعة الإمام عبد الرحمن بن فيصل }
\end{aligned}
$$

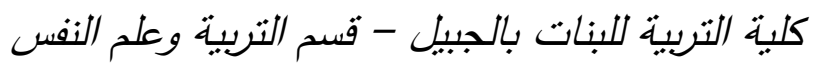

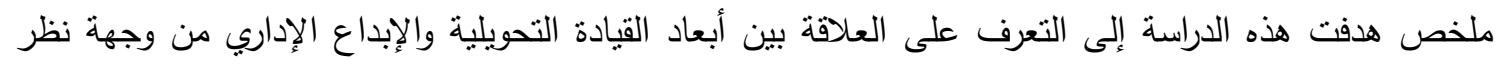

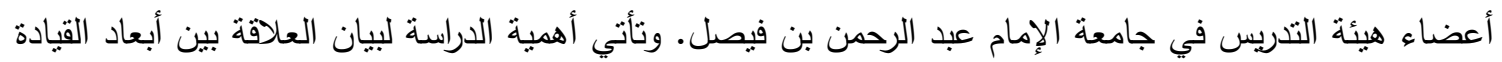

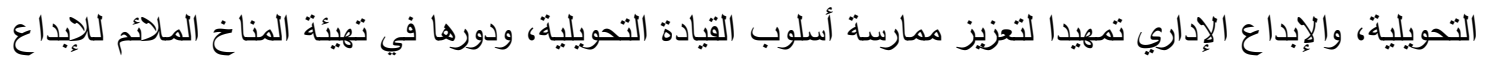

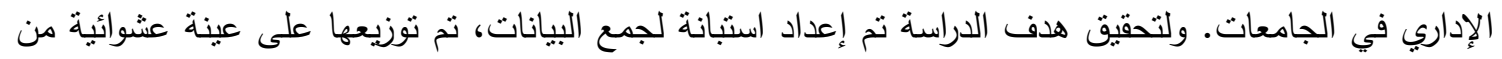
2018/2017 م 2017 م. وأظهرت ننائج الدراسة:

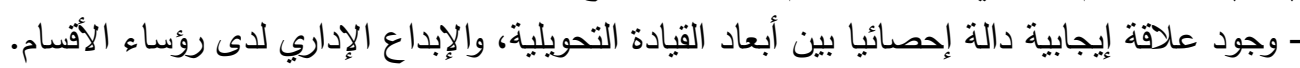

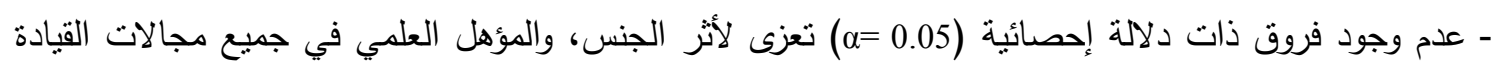

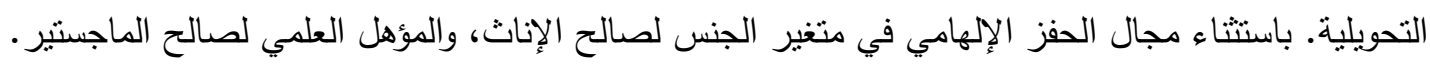

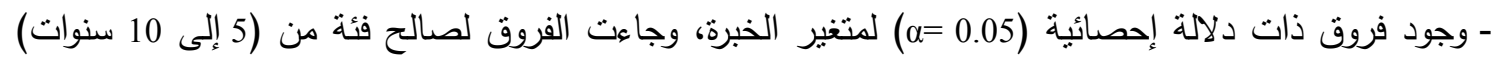
في مجال الحفز الإلهامي، والإبداع الإداري.

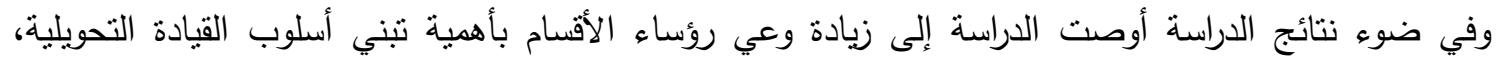

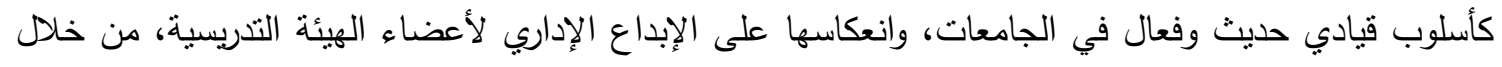

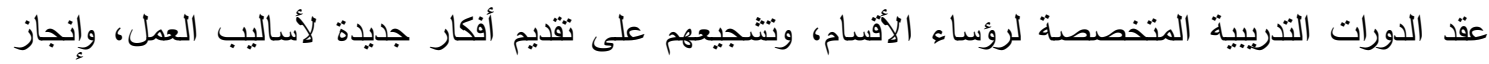

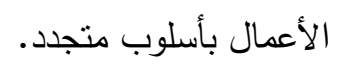
الكلمات الفتاحية: (الإبداع الإداري، القيادة النحويلية).

مما جعل المؤسسات تواجه العديد من التحديات والصعوبات في كيفية مواكبتها وطريقة التكيف معها، وهذه المتغيرات المحيطة بالمؤسسات تثنكل ضغوطات

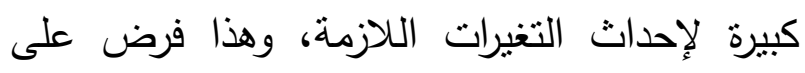
المؤسسات أهمية انتقاء العقول القادرة على الابنكار

\section{مقدمة الدراسة}

بشها العصر الذي نعيش العديد من التطورات، والمتغيرات المنسارعة والمتلاحقة نتيجة الانفجار

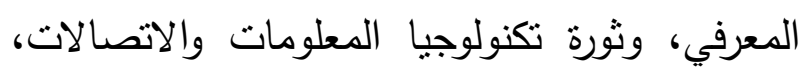


قراتها والاستجابة لهذه المطالب، وتعد مؤسسات التعليم العالي مؤسسات منتجة للإبداع، كونها توفر الخبرة والتدريب للعاملين، حتى يصبح الإبداع حافزا لبقاء المؤسسات، وعاملا رئيسا في تحقيق الفائدة التنافسية. ويتم التعرف على أسلوب القيادة باعتباره أهم العوامل المؤثرة في الإبداع، لأن القادة يمكن أن يؤثروا في التعربف بالأفكار ووضع أهداف محددة، وإيجاد ثقافة الإبداع (Mathew, 2010). لقد أهتم الباحثون في مجال الإدارة والقيادة في فنزة الثمانينيات والتسعينيات من القرن العشربن، بالطرق والأساليب التي تساعد القائد على تطوير المؤسسة، وبعث حياة جديدة فيها، وقد كانت نقطة الانطلاق لتحقيق ذلك لدى العديد منهم هي أعمال ماكجروجر بيرنز (Macgregor Burns). والقيادة عند بيرنز تقهم على أساس أنها: عملية يسعى من (Burns) خلالها كل من القائد والتابعين إلى رفع كل منهما الأخر إلى أعلى مستويات الواقعية والأخلاقية (الهاللي، 2004). ومن الأنماط القيادية التي أفرزها التقدم العلمي والتطور التكنولوجي نمط القيادة التحويلية الذي يعد مدخلا جديدا للقيادة التعليمية التي يسعى القائد فيها لإحداث تغيرات إيجابية في طريقة العمل، والذي من أهم ما يميزه قدرته العالية على قيادة المؤسسة في مواجهة التحديات والتطورات الحديثة من خلال التأثير في سلوكيات المرؤوسين، وتتمية قدراتهم الإبداعية عن طريق فتح المجال لهم،
والتجديد والتصور الصحيح، وتوفير الوسائل المناسبة التي تساعد على ابتكار طرق جديدة، وحلول إدارية سربعة. ومن الأنماط الإدارية التي تساعد المؤسسات على مواجهة التغيرات المتسارعة في تحقيق أهدافها هي القيادة باعتبارها جوهر العملية الإدارية، وأسلوب في غاية الأهمية في العصر الذي نعيش، وأن أهميتها ودورها نابع من كونها تقوم بدور أساسي يؤثر في عناصر العملية الإدارية التي تجعل الإدارة أكثر ديناميكية وفاعلية، وجعلها عملية تعاونية مشتركة تسهم في دفع المؤسسات إلى الأمام. فالقيادة الإدارية أصبحت المعيار الذي يحدد نجاح أي مؤسسة، لأنها تمثل عاملا مهما في نجاح أو فثنل الإدارة، لما فيها من تأثثر مباشر على العملية الإدارية، وقدرة القائد على التأثثر في العاملين وحفزهم لإنجاز أهداف المؤسسة وأولوياتها، والسعي الدائم لتطويرها، وتمكينها من إدارة مؤسسات المستقبل بكفاية وفاعلية. وهذا يفرض تحديا رئيسيا على المؤسسات، ولا سيما المؤسسات التعليمية وذللك بتطوير القيادة من خلال قابلية القيادة للتعلم والتطوير ، وإعادة الصياغة بما بنسجم مع متطلبات العصر، ومستجداته، وتقنياته ضمن إطار فكري حديث.

وقطاع التعليم العالي يتعرض لضغوط من بيئة ديناميكية تثميز بالتغير التكنولوجي السربع وزيادة الطلب على التعليم، وهو ما أثنار اهتمام الأكاديميين والممارسين في المؤسسات التعليمية إلى تطوير 
المستمرة، والرغبة في التحدي، والسعي بصفة دائمة وراء كل ما هو جديد وغير مألوف.

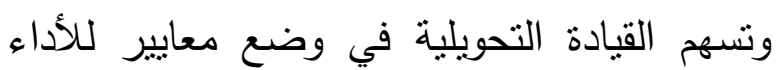
الجامعي، ضمن نسق متكامل ومترابط يجعلها قادرة

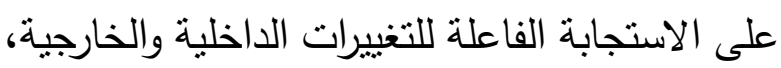
وإحداث تغييرات في ثقافتها ومعتقداتها، وتبرز أهمية القيادة التحويلية وإمكانيه تطبيقها في الجامعات في أنها قيادة فنية إبداعية تتضمن أساليب إدارية على والى درجة عالية من الأهمية (Sergiovanni,1996). وتعمل القيادة التحويلية على رفع مسنوى الأداء الجامعي، وتستجيب بشكل فاعل للتغيرات التي تحدث في مناخ عمل الجامعات، والتقلبات في حاجات العاملين ورغباتهم، وكذلك المتعاملين مع فع

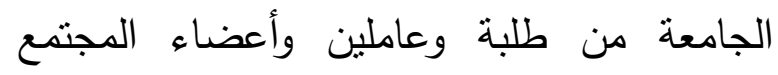
المحلي، فضلا عن رفع ثقة العاملين بالجامعة، وإثعارهم بالمواطنة والانتماء، وتبعث فيهم الدافعية اللازمة لتحقيق الأداء المتميز لضمان جودة باهة العمليات والمخرجات. ولما كانت القيادة التحويلية قيادة فنية إبداعية قادرة على إيجاد جامعات قوية للتعليم بكافّة أنشاله، وقادرة

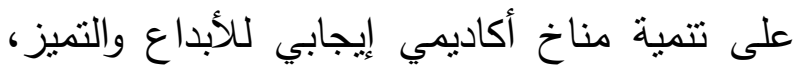
وجدت الباحثة دافعا للبحث في العلاقة بين القيادة التحويلية والإبداع الإداري من وجهة نظر العاب أعضاء هيئة التدريس في جامعة الإمام عبد الرحمن بن

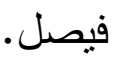

وتتجيعهم على مواجهة المشاكل والصعوبات التي تواجه منظماتهم. فالقيادة التحويلية نمط يمكن استخدامه لوصف مدى واسع من المحاولات الدقيقة للتأثير في المرؤوسين على المستوى الفردي، إلى المحاولات الأكثر اتساعا، للتأثنر في المؤسسات التعليمية والثقافات بأكملها، وعلى الرغم من أن القائد التحويلي يؤدي دورا محوريا في إحداث التغيير إلا أن المرؤوسين والقادة الن يرتبط كل منهم بالآخر في القيادة التحويلية (الرقب، . (2010

وتعمل القيادة التحويلية على تغيير المرؤوسين وتحويلهم إلى قادة، وهي نركز على القيم والأخلاق

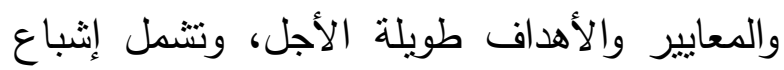
حاجات الأفراد ومعاملتهح بإنسانية، وتتدرج ضمن والهن القيادة ذات الصبغة الكارزماتية والروئية المستقلية، فالقائد التحويلي يقدر الطاقة الكامنة داخل المرؤوسين بحيث يزيد مقدتهم لإنجاز الالتزامات الحالية والمستقبلية المطلوبة منهم بطريقة إبداعية

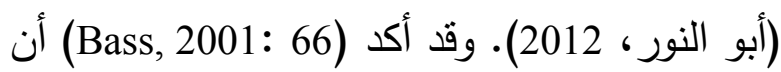
القيادة التحويلية تحث العاملين على تخطي التوقعات

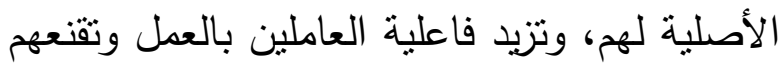
بقبول مهمة المؤسسة التعليمية وأهدافها، وبركز القائد من خلا القيادة التحويلية على أهمية المستقبل، ويعمل على اكتثافه وتعظيم العائد عليه، وتتميز القيادة التحويلية من هذه الزاوية بالحركة 
الحفز الإلهامي) والإبداع الإداري من وجهة نظر

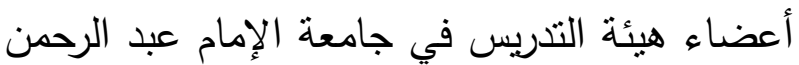

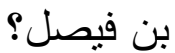
r. هل توجد فروق ذات دلالة إحصائية عند مستوى الدلالة (0.05 =0 م) بين المتوسطات الحسابية لأبعاد القبادة التحويلية (الكاريزما، تقدير الأفراد

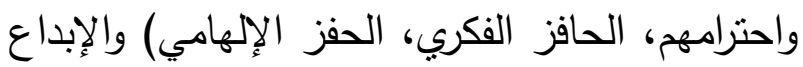
الإداري من وجهة نظر أعضاء هيئة التدريس في الإهي جامعة الإمام عبد الرحمن بن فيصل تعزى لمتغيرات

(الجنس، المؤهل العلمي، الخبرة، الكلية)؟

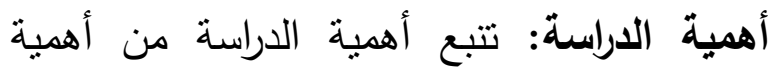
الموضوع الذي تعالجه، إذ إنها تتاقش العلاقة بين

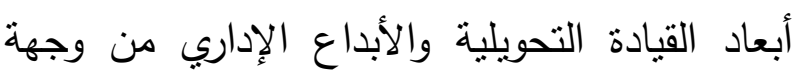
نظر أعضاء هيئة التذريس في جامعة الإمام عبد

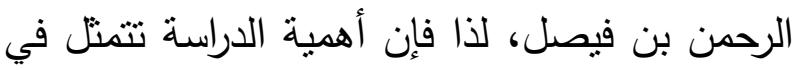

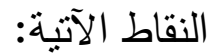
ا ـ تعد الدراسة الأولى حسب علم الباحثة، التي

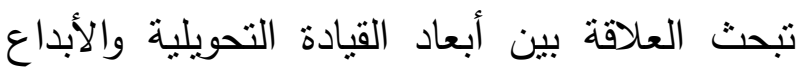
الإداري من وجهة نظر أعضاء هيئة التدريس في لباتي

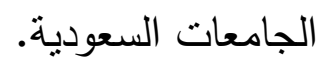
r. توجه انتباه وحدات الجامعة المعنبة بتطوير الممارسات الإدارية للقادة، وتوجيههم بإعداد البرامج لبهاه التدريبية والنطورية في مجال الأنماط القيادية الحديثة وخاصة القيادة التحويلية.

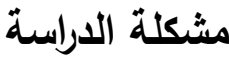

تواجه القبادات الأكاديمية بالجامعات تحديات ومشكلات إدارية كثثرة أثناء القيام بأعمالهم اليومية، حيث تقع على عاتقهم مسؤوليات نتعلق بأعضاء هيئة التثريس، والتغيرات التنظيمية التي تتطلب منهم ضرورة التفكير في التقليل من الاعتماد على المنهج التقليدي، ومحاولة توظيف المنهج الإبداعي. وجامعة الإمام عبدالرحمن بن فيصل من المؤسسات التعليمية الرائدة من حيث تبنيها للوسائل والأساليب القيادية الحديثة المتبعة في تحقيق أهدافها، مما يتطلب منها أن تواكب المستجدات والتطورات، والبحث عن أساليب إبداعية جديدة، والعمل على لئ حسن استغلال الموارد البشرية المؤهلة، وفتح المجال للإبداع. وما لا شك فيه فإن الحاجة لمواجهة المشكلات وتوظيف المنهج الإبداعي، وتوفير البيئة

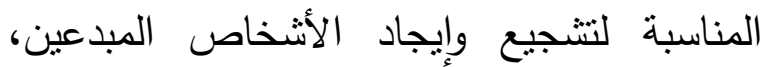
والوسائل اللازمة لتتميته وتطويره مطلب ضروري لكافة المؤسسات التعليمية، لكثرة التحديات والتغييرات التي تواجهها. لذلك تعمل الدراسة الحالية على دراسة العلاقة بين أبعاد القيادة التحويلية والإبداع الإداري من وجهة نظر أعضاء هيئة التدريس في جامعة النهادئ الإمام عبد الرحمن بن فيصل. أسئلة الدراسة: سعت الدراسة للإجابة عن: 1. هل توجد علاقة دالة إحصائيا عند مستوى

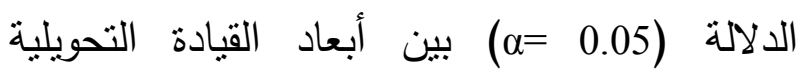
(الكاريزما، تقدير الأفراد واحترامهم، الحافز الفكري، 
- - حدود بشرية: أعضاء هيئة التدريس في جامعة الإمام عبد الرحمن بن فيصل. - - حدود زمانية: طبق هذا لبن فئ البحث خلد العام الدراسي 2017- 2018 م م. - - مدود الموضوع: معرفة العلاقة بين أبعاد القيادة

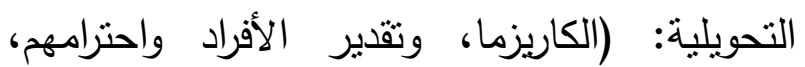
والحافز الفكري، والحفز الإلهامي) والإبداع الإداري من وجهة نظر أعضاء هيئة التدريس في جامعة والإنة الإدية الإمام عبد الرحمن بن فيصل.

\section{مصطلحات الدراسة}

القيادة التحويلية: القيادة التي تعمق مستوى إدراك

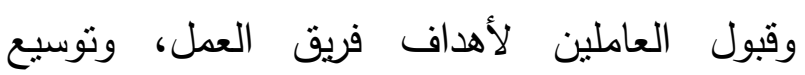
اهتماماتهم والنظر إلى ما هو أبعد من اهنماماتهر

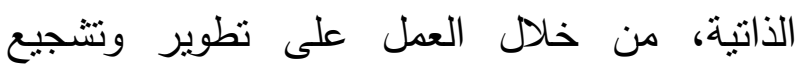
العاملين فكريا وإبداعيا، وتحويل اهتماماتهم الذاتية

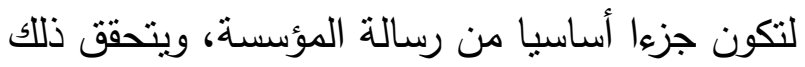
من خلال شخصية القائد التحويلي الداعمة للإبداعات ومبادرات العاملين (قنديل، 2010). وتعرف الباحثة القيادة التحويلية في هذا البحث بأنها أسلوب قيادي يطبقه رؤساء الأقسام في جامعة الإمام عبد الرحمن بن فيصل، بهدف الارتقاء بمستوى أعضاء هيئة التدريس، وخلق بيئة ملاءمة للإبداع والتطوير، والعمل على تتمية وتتجيع القدرات الإبداعية وتطويرها لدى أعضاء هيئة ولئية التدريس. ويقاس باستجابة أعضاء هيئة التدريس عن فقرات استبانة القيادة التحويلية المستخدمة في هذه r. ارتباط القيادة التحويلية بالإبداع الإداري التي تسعى كافة المؤسسات التعليمية لتهيئة المناخ الملائم لتوفر الإبداع لدى أعضاء هيئة التدريس.

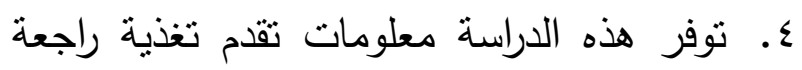
للقيادات في الجامعات عن مستوى ممارسة رؤساء الأقسام الأكاديمية لأبعاد القيادة التحويلية، وما لهذهات لهات الأبعاد من علاقة إيجابيه في الإبداع الإداري. أهداف الدراسة: تتمثل أهداف الدراسة بما يأتي: 1. التعرف على العلاقة بين أبعاد القيادة التحويلية:

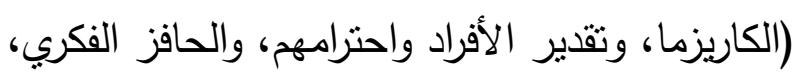
والحفز الإلهامي)، والأبداع الإداري لدى لإنى رؤساء

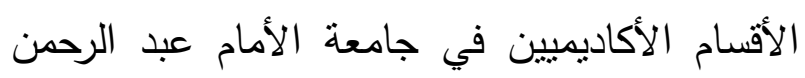
بن فيصل من وجهة نظر أعضاء هيئة التدريس.

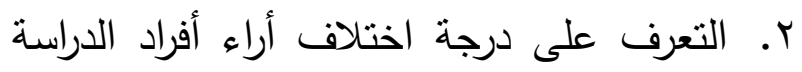
على العلاقة بين أبعاد القيادة التحويلية: (الكاريزما،

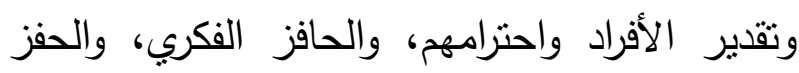
الإلهامي)، والأبداع الإداري لدى رؤساء الأقسام

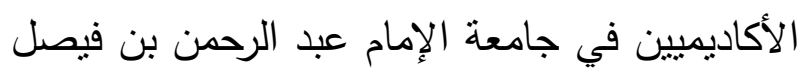
من وجهة نظر أعضاء هيئة التدريس باختلاف متغيرات الدراسة: (الجنس، والكلية، والخبرة، والمؤهل العلمي). r. التوصل إلى مجموعة من التوصيات والمقترحات المناسبة التي تسهم في تفعيل نمط القيادة التحويلية لدى رؤساء الأقسام الأكاديميين من فئن أجل توظيف الإبداع الإداري. حدود الاراسة: اقتصرت هذه الدراسة على: 
(الكارزماتي)، والاهتمام بالأفراد ورعايتهم، والتشجيع

$$
\text { الإبداعي (العامري 2002). }
$$

وقد ركز بيرنز(Burns) على القيادة التحويلية التي يسعى القائد من خلالها إلى الوصول إلى الدوافع

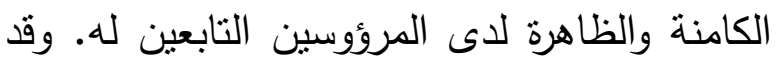

شهدت القبادة التحويلية نطورا ملحوظا من خلال إسهامات باس (Bass) عندما وضع نظرية منهجية علمية للقيادة التحويلية، ووضع لها نماذج ومقاييس علمية لقياس عوامل السلوك القيادي، وهو ما يعرف بمقياس(MLQ) الذي تضمن ثلاثة عناصر للقيادة التحويلية هي: الكاريزما والنتجيع الإبداعي والاهتمام بالفرد). ثم أضاف باس (Bass) في عام 1990، مكونا رابعا أطلق عليه (الحفز الإلهامي). وفي عام 1993، قدم كل من باس (Bass) وأفوليو أنموذجا أكثر حداثة للقيادة التحويلية (Avolio) والإجرائية، يتضمن سبعة عناصر ، ثلاثة منها تحدد القيادة الإجرائية، والأربعة الأخرى تحدد القيادة

$$
\text { التحويلية (الهلالي، 2004). }
$$

\section{مفهوم القيادة التحويلية:}

لم يتفق الباحثون على تعريف محدد للقيادة

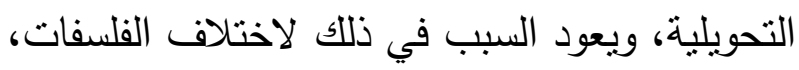
ووجهات النظر حول القيادة التحويلية، حيث تعد من المفاهيم الحديثة في الإدارة، الأمر الذي نتج عنه تعدد التعريفات، وسنقدم هنا بعض التعاريف: - تعريف بيرنز (Burns) الذي عرف القيادة التحويلية بأنها عملية يسعى من خلالها القائد
الدراسة والتي تثمل الأبعاد: (الكاريزما، وتقدير

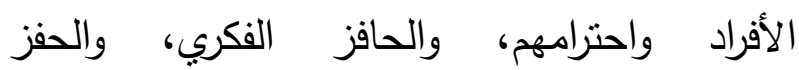
الإلهامي). أبعاد القيادة التحويلية: هي العناصر التي تكون القيادة التحويلية ممنلة في: (الكاريزما، وتقدير الأفراد واحترامهم، والحافز الفكري، والحفز الإلهامي).

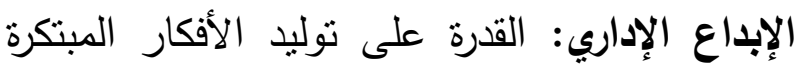
والمفيدة، وتقديم الحلول إلى المشاكل والتحديات اليومية التي تواجهها المؤسسات والعاملين في إطار

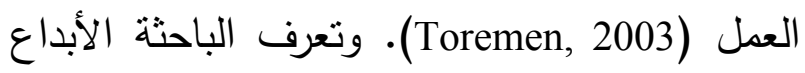
الإداري في هذا البحث بأنه: قدرة رؤساء الأقسام

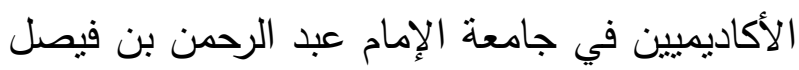
على استخدام أساليب التفكير الحديثة، والقدرات العقلية، وابتكار وإيجاد طرق وأساليب جديدة لتسيير الأعمال، وتقديم الحلول للمشاكل والتحديات التي واني تواجها الأقسام، وأعضاء هيئة التدريس في إطار

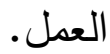

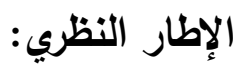
تعد القيادة التحويلية اليوم من أكثر أساليب القيادة شهرة لتطوير المؤسسات، وهي النوع من القيادة الذي مئي تحتاجه مؤسسات اليوم ذات التغير المتسارع، فهي تقوم على إحداث تغييرات جذرية عن طريق إقناع المرؤوسين للنظر إلى ما هو أبعد من مصالحهم الثخصية، من أجل المصلحة العامة للمؤسسة، وتوسيع اهتماماتهم، وتعديق مستوى إدراكهم، وقبولهم لروية وأهداف المؤسسة عن طريق التأثير المثالي 
- تعريف كيركلاند Kirkland (2001) وقوامه أن القيادة التحويلية هي القيادة التي تتجاوز تقديم الحوافز مقابل الأداء المرغوب إلى تطوير وتتجيع المرؤوسين فكريا، وإبداعيا، وتحويل اهتماماتهم الذاتية لتكون جزءا أساسيا من الرسالة العليا ل للمنظمة.

ومن خلال التعريفات السابقة يمكن القول بأن القيادة التحويلية هي القيادة التي تركز على بناء رؤية

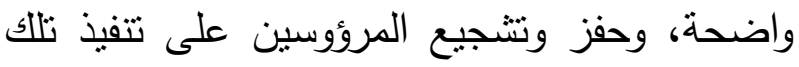

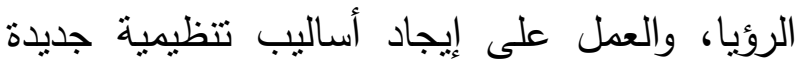
تتوافق مع متطلبات المستقبل، ورفع مستوى الدافعية

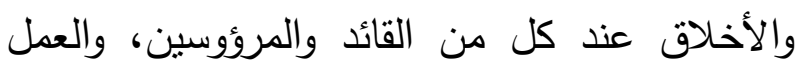
على تغيير وتبديل الأنظمة القائمة لتلائم هذه الروئة،

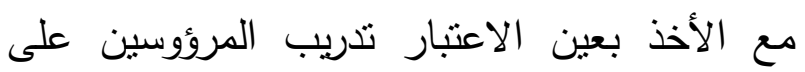
تحمل أكبر قدر من المسؤولية في تتمية وتطوير

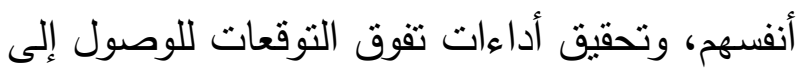
ما يعرف بالإبداع الإداري. أبعاد القيادة التحويلية: للقيادة التحويلية أربعة أبعاد انتنملت عليها استبانة القيادة متعددة العوامل (Readership Multifactor) (Questionnaire MLQ

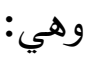
ا ـالكاريزما (التأثثر المثالي (IdealizedInfluence): تمنل قدرة القائد على بناء التقة فيه وتقديره من قبل أتباعه، الأمر الذي يشكل الأساس لقبول التغيير الثامل في المؤسسة التعليمية، وتشير إلى أن القائد
والمرؤوسون إلى نهوض كل منهم بالآخر، للوصول

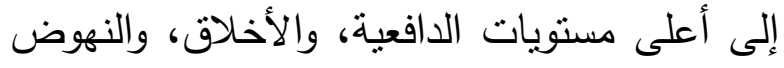
بشعور المرؤوسين، وذلك من خلال الاحتكام إلى إلى أفكار وقيم أخلاقية مثل الحرية، والعدالة، والمساواة .(Bass, 1985) - تعريف العامري (2002) للقيادة التحويلية بأنها القيادة التي تضع روئية واضحة لمؤسساتها، والعمل

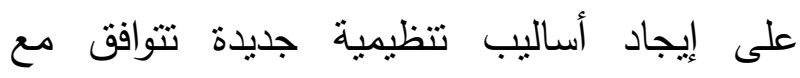
منطلبات المستقبل. - تعريف هاوس (2006) الذي ينص على أن

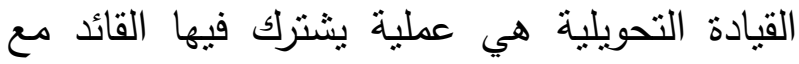
المرؤوسين بروابط ترفع من مستوى الدافعية والأخلاق، عند كل من القائد والمرؤوسين. - تعريف عباس (2003) الذي يرى أن القيادة التحويلية هو ذلك النمط من القيادة التي تنتخدم الإبداع في التأثير على العاملين، وتعتمد الحوار لتعرف كيفية أداء العمل، وتحديد سبله ووسائله، وتنتخدم الطرق غير الاعتيادية لتجاوز الواقع المألوف في العمل المؤسسي، ومحاولة إثرائه وتحسين مناخه. - تعريف ترافينو Trafino (2000) الذي ينص على أن القيادة التحويلية تهتم بمدى سعي القائد

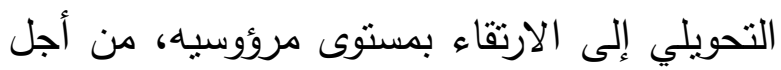
الإنجاز والنطوير الذاتي، والعمل على تتمية وتطوير الجماعات والمؤسسة ككل. 
مفهوم الإبداع الإداري نظرا للتقدم الهائل في العلم والمعرفة، وما ينتج عنه الإدي من تغيرات في مختلف مجالات الحياة، تواجه المؤسسات العديد من التحديات، مما يتطلب منها التكيف معها للبقاء والاستمرار • حيث أن التغير

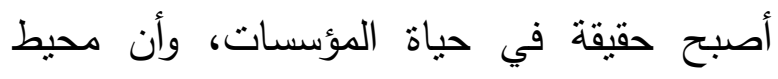
المؤسسات الإدارية أصبح يتشم بالديناميكية، لذا لذان

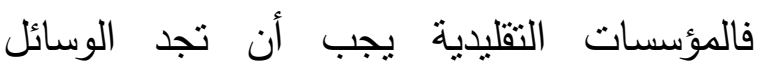
والأساليب التي تمكنها من تجديد نشاطها والاستفادة

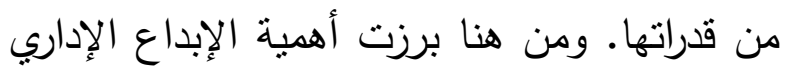

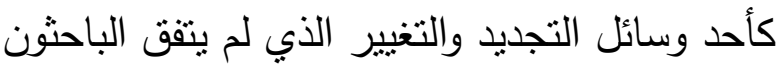

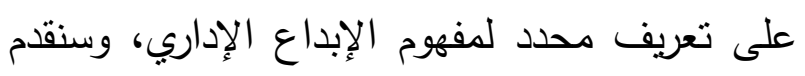
هنا بعض التعاريف: - - تعريف القحطاني (2003) الذي عرف الإبداع الإداري بأنه استخدام الموظف لمهاراته الثخصية

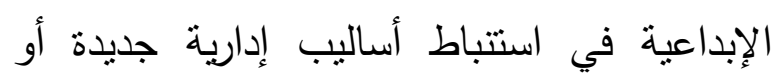
توصله إلى حلول ابتكارية لمشكلة إدارية تواجه مصلحة التتظيم أو تصورات جديدة لمعالجة تلك الك

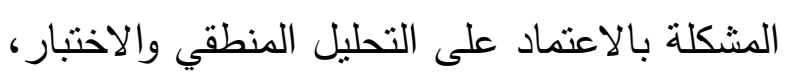
والتجريب، والتقويم. - تعريف العازمي (2006) الذي يرى أن الإبداع يكمن في قدرة الأفراد العاملين على استخدام أساليب التفكير الحديثة، والقدرات الفعلية والذهنية، وابتكار طرائق جديدة تتسم بتحقيق المنفعة العامة.

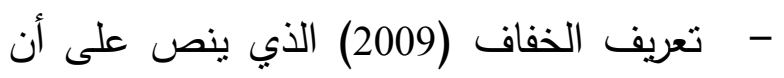
الإبداع الإداري هو عملية الخروج من الحالة
يحظى بدرجة عالية من الاحترام والتقة من قبل تابعيه، وتهنم بصفة أساسية بتطوير رؤية جديدة تعد بله نموذجا للمنل والسلوكيات المشتركة. r. الاستثارة الفكرية (Intellectual Simulation): تشير إلى أن القادة يعملون على تحفيز مرؤوسيهم على المبادرة، والابتكار، والإبداع والتغيير في لئي أسلوب التفكير بالمشكلات القائمة، وتتاولها بطرق والابلى ولعير جديدة، والنظر إليها من زوايا عديدة لجعهم أكثر بالمئرة وعيا بالمشكلات التي يتعرضون إليها. r. الحفز الإلهامي (Inspirational Motivation): يكون القادة فيها عبارة عن أنموذج لزيادة الوعي والفهر بالأهداف المرغوبة المنبادلة، حيث إن أفعالهم تؤثنز في المرؤوسين وتدفعهم إلى تمنل خطواتهم ويتضمن إلهام المرؤوسين واستثارة همهمج، وإذكاء الحماس لديهم نحو الإنجاز من خلال تقديم رؤية

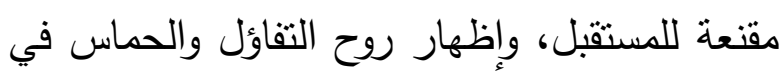
العمل، وتوفير نوع من التحدي في عمل المرؤوسين، لونها واستثارة روح الفريق لدى المرؤوسين. ع.رعاية الأفراد (Individualized Consideration): يتم التعامل مع المرؤوسين بطرق مختلفة يراعي فيها

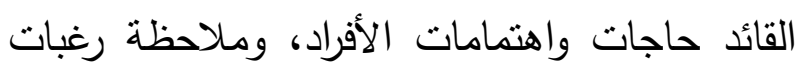

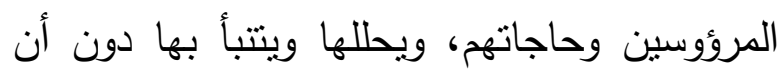
يشعرهم أنهم موضع للملاحظة، وبالتالي يوكل

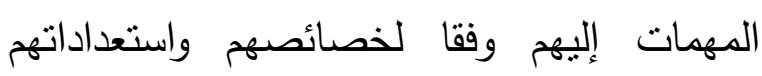
الثخصية (Kirkland, 2011). 
توظيف المنهج الإبداعي، لذا لم تعد مهمة القائد تتمثل في انتظار حدوث المشكلات، والتذخل في محاولة حلها بشكل جزئي أو اقتلاع جذورها الأساسية، بل الأمر تعدى ذلك بكثير ، حيث أصبح من أهم واجبات القائد أن يأخذ بزمام المبادرة، ويتوقع ما يمكن أن يحدث، ويفكر وبيدع في كيفية تلافي حدوث المشكلات، عوضا عن مواجهتها عقب حدوثها. وفيما يلي نستعرض العلاقة بين السلوك القيادي التحويلي، ومدى توافر القدرات الإبداعية لاى العاملين، وذللك من خلال التطرق إلى عناصر القيادة التحويلية كلا على حده (العازمي، 2006):

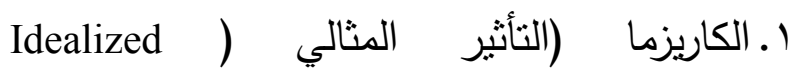
Influence): يستطيع القائد أن يجعل من نفسه أنموذجا لروح الابتكار وقدرته على إلهام الآخرين، فالصفات الثخصية للقائد لها تأثير كبير على فتح المجال أمام العاملين للإبداع والابتكار، فالقدرة على الإقناع من السمات الأساسية التي يجب أن يتحلى بها القائد، فلا يكفي أن بكون القائد متحمسا، ولكن يجب أن يكون قادرا على إثارة حماس الآخرين للإبداع والابتكار، فالقائد يستطيع أن يبعث الهمم وبشجع مبدأ التجريب والمبادأة، وبث الثقة بالنفس، والتأكيد على أن كل إنسان قادر على الإبداع طالما توافرت له عوامل الإبداع ومناخه المناسب، وتشجيعهم على عدم التقيد بالمألوف والخبرات السابقة، من خلال إتاحة الفرص للمشاركة، وإبداء الرأي، واتخاذ بعض القرارات.
التقليدية إلى التغيرات التتموية المستمرة، بروئة إدارية حديثة تستثر الإبداع في خدمة المجتمع، وتلبية

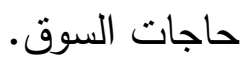
- تعريف الصيرفي (2003) وقوامه أن الإبداع الإداري هو فكرة تتسم بالحداثة والتجديد، تتشأ نتيجة الخبرة والإلمام الإداري المدرك لواقع المؤسسة والمستتد إلى المعلومات الثاملة لأجزائها المختلفة وتحليلها. ومن خلال التعريفات السابقة يظهر لنا أهمية الإبداع الإداري، والحاجة إليه في المؤسسات؛ لتبني أفكار إبداعية واستخدامها كسلاح للتغيير والتطوير، وحل المشكلات لتحسين أداء المؤسسات وفاعليتها وتحقيق أهدافها. ومن هنا يمكن أن نعرف الإبداع الإداري بأنه عملية ذات مراحل متعددة يعمل فيها المرؤوسون على تبني أفكار خلاقة، وما ينتج عنها من إنجازات إبداعية مختلفة، بأكبر قدر من: (الطلاقة، والمرونة، والأصالة، والحساسية للمشكلات)، بحيث تحدث نقلة مميزة على مستوى المؤسسة وتتفيذها من قبل المرؤوسين، والقدرة على تكوين علاقات جديدة التي من الممكن تتميتها وتطويرها بحسب قدرات الأفراد، والجماعات، والمؤسسات. العلاقة بين القيادة التحويلية والإبداع الإداري: على القادة والعاملين في المؤسسات على اختلاف أنواعها، وأحجامها، ومهامها، ضرورة التفكير في التقليل من الاعتماد على المنهج التقليدي القائم على المحاولة والخطأ في حل المشكلات، ومحاولة 
مسؤوليات القائد إيجاد بيئة اجتماعية إيجابية تساعد على الإبداع والابتكار داخل المؤسسة، فالقائد الذي لئي

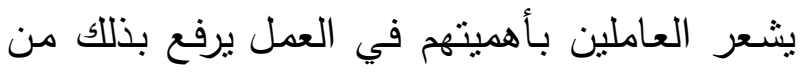

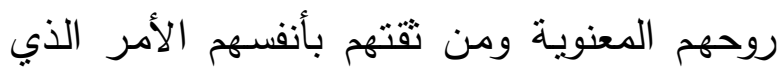

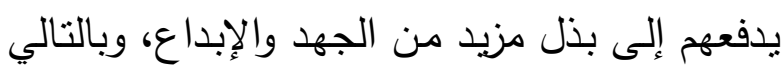
إلى التقام وزيادة الإنتاج. ومما سبق نخلص إلى أهمية الدور الفعال للقيادة وليادة الإناء

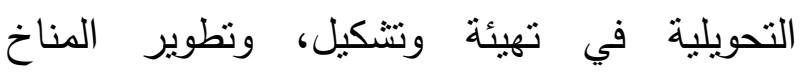
التنظيمي للإبداع، وجله أكثر انفتاحا وتبادلا للخبرات، وتقبلا للرأي الآخر ، وذللك من خلاعل العمل لكل على تبني سلوكيات تساعد على الارتقاء بقدرات

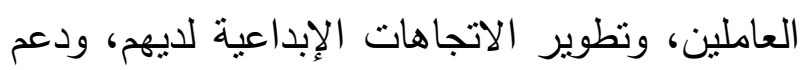

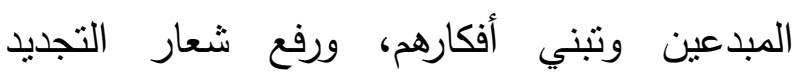
والإبداع، باعتباره هدفا تسعى إلبه المؤسسة والأفراد على حد سواء.

\section{الدراسات السابقة}

هدفت دراسة (الحسيني والبلتاجي، 2016) بعنوان "القيادة التحويلية والابتكار دراسة مقارنة بين التعليم العالي العام والخاص في العراق" إلى معرفة نأثثر

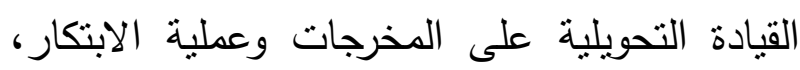
والاختلافات بين هذه الآثار في مؤسسات التعليم

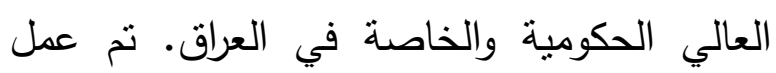
استنيانات ومقابلات ل (439) عضو هيئة تدريس

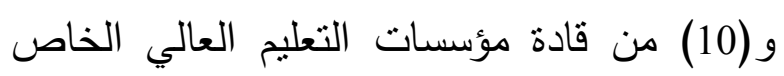

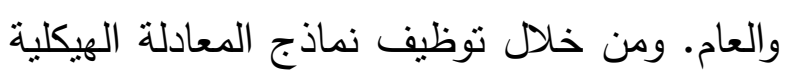

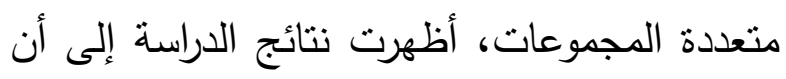

r. الاستثارة العقلية (التشجيع الإبداعي (Intellectual Simulation) تشجع العاملين على الإبداع والابتكار، هي درجة الهم العوالئ الحرية التي يوفرها القائد للعاملين، فإناحة الفرصة للعاملين للمشاركة وإبداء الرأي وتقديم الاقتراحات والحلول لبعض المشكلات الإدارية، تشعر العاملين

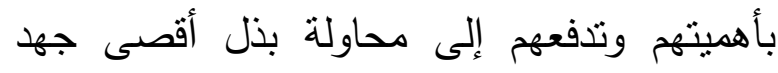

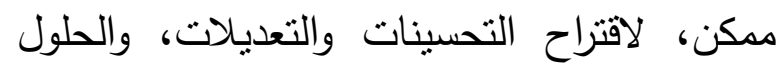

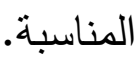
r. الحفز الإلهامي (Inspirational Motivation): اهتمام القائد بالمشاعر والعواطف لإى العاملين، لتحفيزهم على العمل، والحركة، والقيادة الإلهامية، وحرصه على أداء المهام بأفضل طريقة ممكنه، لن لن النهل يتحقق له النجاح إذا لم يكن قدوة لمرؤوسيه في الدقة

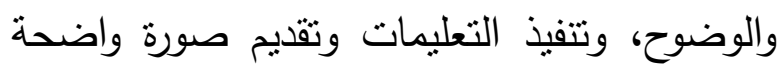

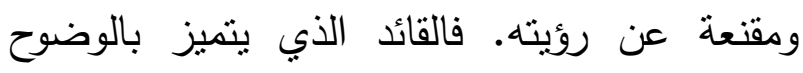
والثفافية في العمل يوفر دافعا نفسيا هاما يدفع لعانه العاملين لتقديم أفضل ما لديهج من قدرات ومهارات، ويبدو أن قدرة القائد على إذكاء روح التتافس بين العاملين نساعد على استتارة قدراتهم الإبداعية للوصول إلى اقتراحات وأفكار تتسم بالجدية والأصالة.

ع. رعايـة الأفراد (IndividualizedConsideration):

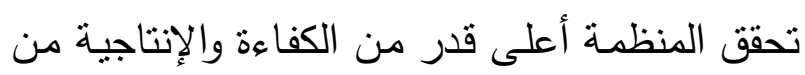
خلا إيجاد مناخ يمتاز بدفء العلاقات الإنسانية

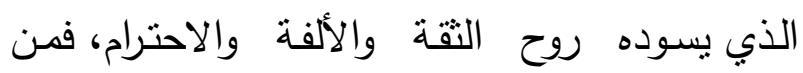


مرتفعة جدا، وكانت على مستوى أبعاد (التأثير المثالي،

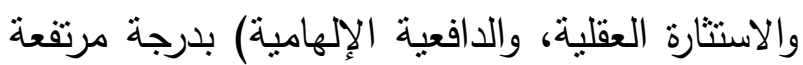
جدا أيضا، في حين كانت درجة النطبيق لبعد (رعاية الأفراد) مرتفعة من وجهة نظر القادة الإداريين فيها. وخلصت الدراسة إلى عدة توصيات أهمها: - - مصميم برامج لتنمية القادة في مؤسسات التعليم العالي، بحيث يتضمن منهجا تقنيا يأخذ في الاعتبار أفضل الممارسات للقيادة التحويلية. - إجراء دراسات ممانتة تطبّق على كل جامعة على حدة. Moolenaar, Daly \& وقام مولنير وديلي وسليقرز Sleegers,

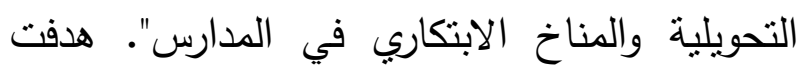
الدراسة إلى التعرف على العلاقة بين القيادة التحويلية في المدارس والمناخ الابتكاري في البيئة المدرسية. استخدم الباحثون المنهج الوصفي والاستبانة كأداة للدراسة، تم تطبيقها على عينة من لن المعلمين بلغت (702) معلما و(51) من مديري المدارس في هولندا، توصلت الدراسة إلى أن هنالك ارتباط إيجابي بين القيادة التحويلية، ومناخ البيئة المدرسية المبتكرة، وأن هناك استعداد لاى المعلمين للتغيير، واكتساب المعارف الجديدة، وممارسة

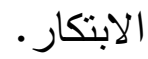

Sibbas, للك أجرى عباس، واقبال، ووحيد، وريز (2012) Iqbal, Waheed, \& Riaz, "العلاقة بين نمط القيادة التحويلية والسلوك التنظيمي
القيادة التحويلية تلعب دورا محوريا في تعزيز المخرجات وعملية الابتكار ، وأن الأسلوب من شأنه

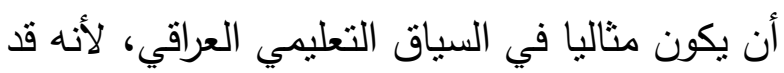
يعزز استراتيجيات تطوير الابتكار في كلا القطاعين، كما كثفت المقابلات أن هنالك أوجه تشابه واختلاف بين مؤسسات التعليم العالي العام والخاص في العراق، فيما يتعلق بالعلاقة بين القيادة

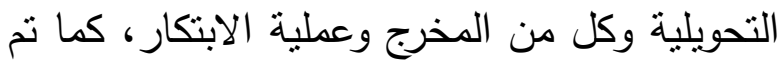
تطوير مبادئ توجيهية للباحثين والقادة، وقدمت أدلة

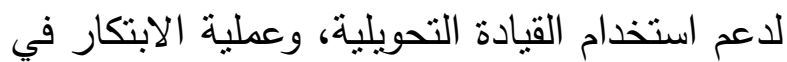
التعليم العالي في البلدان النامية، وخاصة العراق، وتم أيضا مناقثنة الآثار المنرتبة على لنتائج واقتراحات البحث في المستقبل. وأجرى (ناصرالدين، وشقوارة، والحيلة، 2013) دراسة بعنوان "درجة تطبيق أبعاد القيادة التحويلية في ولئي الجامعات الأردنية الخاصة من وجهة نظر القادة الإداريين فيها". هدفت الدراسة إلى استقصاء درجة تطبيق أبعاد القيادة التحويلية في الجامعات الأردنية الخاصة من وجهة نظر القادة الإداريين فيها، ولتحقيق هذا الهدف نم اختيار الجامعات الأردنية الخاصة، والقادة الإداريين فيها. ولجمع البيانات من لهن أفراد عينة الدراسة استخدمت استبانة القيادة التحويلية المتوسطات الحسابية والانحرافات المعياريّة، واختبار

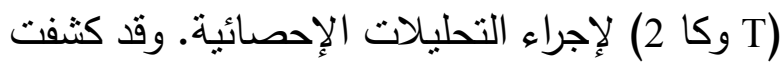
نتائج اختبار الفرضيات الصفرية أن الجامعات الأردنية الخاصة تطبق أبعاد القيادة التحويلية بدرجة التبار الجية 
الثرق الأوسط من وجهة نظر أعضاء الهيئتين

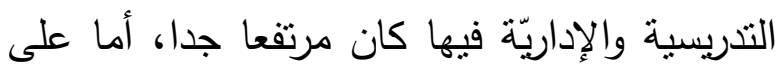

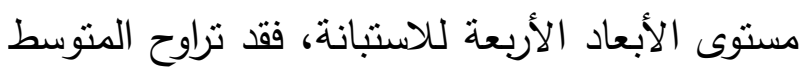
الحسابي بين مرتفع جدا لبعد الدافعية الإلهامية

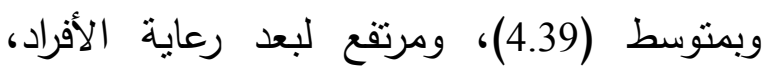
وبمتوسط حسابي (4.09)، في حين لم يكثنف اختبار عن وجود فروق ذات دلالة إحصائية عند الدابئ (T)

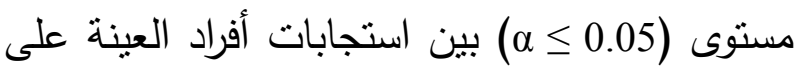

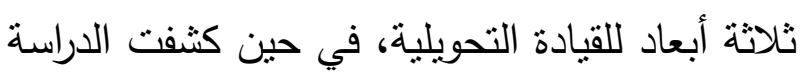
عن وجود فروق ذات دلالة إحصائية عند مستوى الدلالة (0.05 م) لبعد الدافعية الإلهامية ولصالح أعضاء هيئة التدريس. وأجرى باشام Basham (2010) دراسة استقصت الموضوعات التي تواجه رؤساء الجامعات الذين يطبقون القيادة التحويلية والقيادة التبادليّة (Transformational and transactional leaders) لحل المشكلات التي نواجههم. أظهرت نتائج الدراسة أن الخبراء اختاروا (41) معيارا تضم العديد من

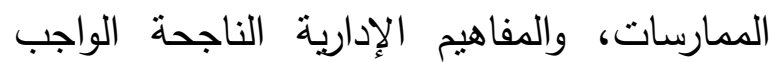
توافرها في رؤساء مؤسسات التعليم العالي (الجامعات)، وأن (61٪) من هذه المعايير متوسطة، بينما (56 ٪) منها ذات مسنوى دال إحصائيا. وكان من أهم نتائجها: أن غالبية رؤساء الجامعات يفضلون تطبيق القيادة التحويلية، ويقدرون وجود بيئة جامعية متميزة تدعمها الثقة، وعليهم تطبيق نمطي القيادة (التحويلية التبادلية) لضمان إحداث تغيير
الإبداعي في المؤسسات التعليمية". هدفت الدراسة إلى دراسة العلاقة بين جوانب القيادة التحويلية وسلوك العمل الإبداعي بين العاملين في المؤسسات التعليمية. تم استخدام ارتباط بيرسون لدراسة العلاقة بين القيادة التحويلية، وجوانب السلوك الإبداعي للعاملين. وأظهرت نتائج الدراسة بأن هناك تأثير التير

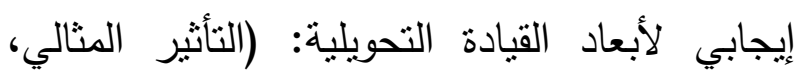
ورعاية الأفراد، والاستثارة الفكرية، والحفز الإلهامي). وأن هناك ترابط بين أبعاد القيادة التحويلية، وتعزيز سلوك العمل الإبداعي بما في ذلك تعزيز الأفكار

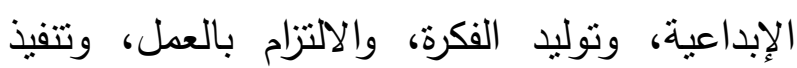
الفكرة الإبداعية. أوصت الدراسة بضرورة تطبيق

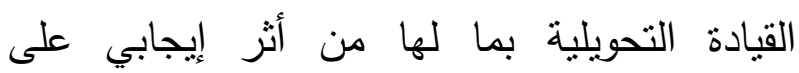

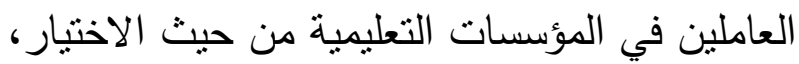
والتعين وتعزيز السلوك الإبداعي للعاملين. وفي دراسة قامت بها شقوارة (2012) بعنوان "درجة تطبيق القيادة التحويلية في جامعة الشرق الأوسط من وجهة نظر أعضاء الهيئتين التدريسية والإداريّة فيها". هدفت إلى تعرف درجة نطبيق القيادة

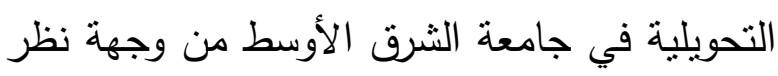

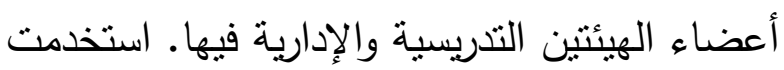

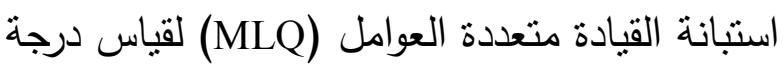
تطبيق القيادة التحويلية بشكل عام، وأبعادها الأربعة: (التأثير المثالي، ورعاية الأفراد، والاستثارة العقلية، والدافعية الإلهامية) بشكل خاص. أشارت نتائجها

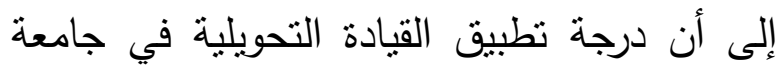


فيصل التابعة للعام الدراسي (2018/2017)، والبالغ عددهم (1311) فردا. قامت الباحثة بأخذ عينة عشوائية اشتملت على (225) عضو هيئة تدريس في جامعة الإمام عبد الرحمن بن فيصل تم اختيارها بناء على متغيرات الدراسة: (الجنس والمؤهل العلمي والخبرة والكلية) والجدول رقم (1) يبين توزيع أفراد عينة الدراسة حسب متغير الجنس والمؤهل العلمي

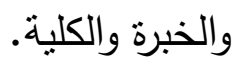

على مستوى الأفراد والكليات نتيجة للاهنمام الثخصي بهما، وأن رؤساء الجامعات يتمتعون الثرات بالحماسة اللازمة لتطبيق القيادة التحويلية والقيادة

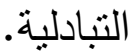
منهجية الاراسة: وتتشمل على ما يأتي: مجتمع وعينة الدراسة:

تكون مجتمع الدراسة من جميع أعضاء هيئة التنريس العاملين في جامعة الإمام عبد الرحمن بن

جدول (1) التكرارات والنسب المئوية لجميع أعضاء هيئة التدريس العاملين في جامعة الإمام عبد الرحمن بن فيصل حسب متغيرات الاراسة

\begin{tabular}{|c|c|c|c|}
\hline النسبة & التكرار & الفئات & \\
\hline 37.3 & 84 & ذكر & \multirow[t]{2}{*}{ الجنس } \\
\hline 62.7 & 141 & أنثى & \\
\hline 30.7 & 69 & ماجستير & \multirow[t]{2}{*}{ المؤهل العلمي } \\
\hline 69.3 & 156 & دكتوراه & \\
\hline 30.2 & 68 & أقل من 5 سنوات & \multirow[t]{4}{*}{ الخبرة } \\
\hline 35.1 & 79 & من 5 إلى 10 & \\
\hline 16.0 & 36 & من 10 إلى 15 & \\
\hline 18.7 & 42 & 15فأكثر & \\
\hline 66.2 & 149 & إنسانية & \multirow[t]{2}{*}{ المؤهل العلمي } \\
\hline 33.8 & 76 & علمية & \\
\hline 100.0 & 225 & المجموع & \\
\hline
\end{tabular}

الأقسام الأكاديمية. وقد مرت الاستبانة بعدة مراحل حتى وصلت إلى شكلها النهائي، وهذه المراحل هي:

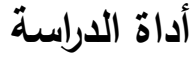
لتحقيق هدف الدراسة قامت الباحثة بإعداد استبانة المرحلة الأولى: تم الاطلاع على الأدب النظري

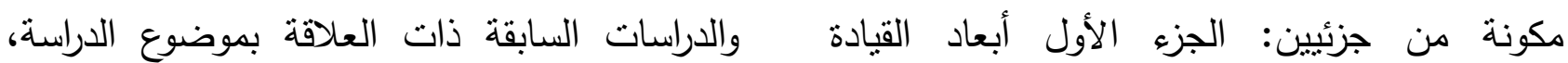

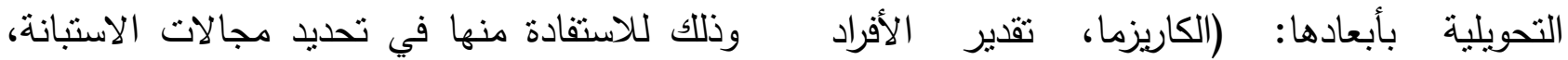
واحترامهم، الحافز الفكري، الحفز الإلهامي) للى وصياغة الفقرات التي تمثل كل مجال. المرحلة الثانية: نم عرض الاستبانة بصورتها

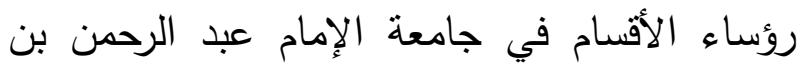
فيصل، والجزء الثاني الإبداع الداري لاى رؤساء الأولية على مجموعة من المحكمين المتخصصين 
في جامعة الإمام عبد الرحمن بن فيصل، وذللك وضوحها، وملائمة فقراتها لمجالاتها. ويوضح للتأكد من دقة وصحة فقرات الاستبانة، ومدى الجدول رقم (2) عدد فقرات كل مجال. جدول (2) مجالات العلاقة بين أبعاد القيادة التحويلية والإبداع الإداري لأعضاء هيئة التدريس في

جامعة الإمام عبد الرحمن بن فيصل

\begin{tabular}{|c|c|c|c|}
\hline عداد الفقرات & أرقام الفقرات في الاستبانة & المجال & الرقم \\
\hline 10 & $1-10$ & الكاريزما & 1 \\
\hline 9 & $11-19$ & تققير الأفراد واحترامهم & \\
\hline 8 & $20-27$ & الحافز الفكري & \\
\hline 9 & $28-36$ & الحفز الإلهامى & \\
\hline 20 & $37-56$ & الإبداع الإداري & r \\
\hline 56 & & & 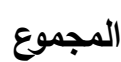 \\
\hline
\end{tabular}

في تخصص الإدارة التربوية، والتحليل الإحصائي، للتحقق من صدق محتواها، ونم الأخذ بملاحظاتهر وإجراء التعديلات لصياغة فقرات الاسنيان لتكون

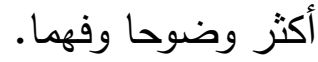

ثبات أداة الاراسة

للتأكد من ثبات أداة الدراسة، تم حساب معامل الثبات بطريقة الاتساق الداخلي حسب معادلة كرونباخ ألفا للمجالات والأداة ككل، إذ بلغت قيمته الافله لأبعاد القيادة التحويلية ككل (0.95)، والعلاقة بين أبعاد القيادة التحويلية والإبداع الإداري (0.92)، واعتبرت هذه النسب مناسبة لغايات هذه الدراسة، الجدول رقم (3) أدناه يوضح معامل الاتساق الداخلي

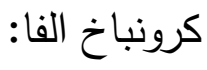

وقد اعتمدا الباحثة مقياسا خماسيا وفقا لترج ليكرت لمعرفة أبعاد القيادة التحويلية بأبعادها: (الكاريزما، وتقدير الأفراد واحتراده، والحافز الفكري، والحفز

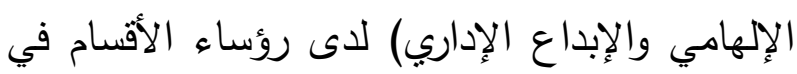
جامعة الإمام عبد الرحمن بن فيصل وعلاقتها بالإبداع الإداري. وتحسب العلامة النهائية لكل مجال، وفقًا لمجموع الإجابات لكل فقرة من الفقرات وفق سلم ليكرت المتعدد الخماسي، فكانت مستويات الإجابة: (درجة كبيرة جدا (5)، ودرجة كبيرة (4)، ودرجة متوسطة (3)، درجة متدنية (2)، ودرجة متننية جدا (1). صدق أداة الدراسة نم التحقق من صدق المحتوى لأدوات الدراسة

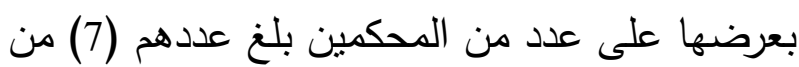
المحكمين المختصين ممن يحملون شهادة الدكتوراه 
جدول (3) معامل الاتساق الداخلي كرونباخ ألفا للمجالات والدرجة الكلية

\begin{tabular}{|c|c|}
\hline الاتساق الااخلي & 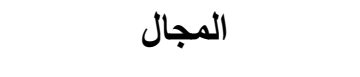 \\
\hline .86 & الكاريزما \\
\hline .85 & تقدير الأفراد واحترامهم \\
\hline .81 & الحافز الفكري \\
\hline .81 & الحفز الإلهامي \\
\hline .95 & أبعاد القيادة التحويلية ككل \\
\hline .92 & الإبداع الإداري \\
\hline
\end{tabular}

ثانيا: المتغير التابع: الأبداع الإداري لدى رؤساء الأقسام الأكاديمية في جامعة الإمام عبد الرحمن بن الإداري لإن رؤساء منهج الدراسة فيصل. بالإضافة إلى المتغيرات المتعلقة بعينة

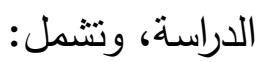
استخدمت الباحثة في هذه الدراسة المنهج الوصفي وذلك لملائمته لطبيعة أهداف الدراسة وأسئلتها. ا ـ الجنس، وله فئتان: (ذكر ، وأنثى). الأساليب الإحصائية

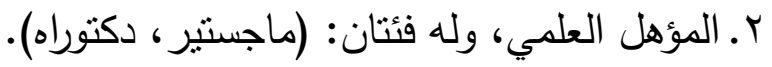
تم استخدام المتوسطات الحسابية والانحرافات المعيارية ومعامل ارتباط بيرسون ومعامل الثبات بطريقة الاتساق الداخلي حسب معادلة كرونباخ ألفا واختبار (ت) وتحليل التباين الأحادي واختبار إليها الدراسة وفق تسلسل أسئلتها: المقارنات البعدية بطريقة شيفيه. عرض نتائج السؤال الأول: هل توجد علاقة دالة متغيرات الاراسة: نتاولت هذه الدراسة المتغيرات إحصائيا عند مستوى الالالة (a=0.05 ) بين أبعاد

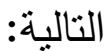

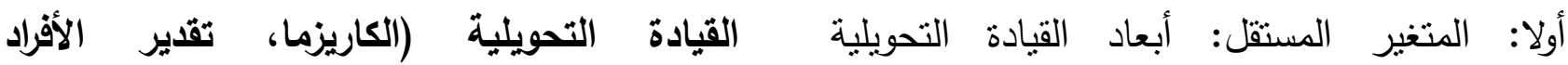

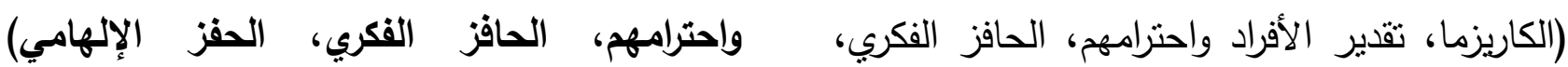

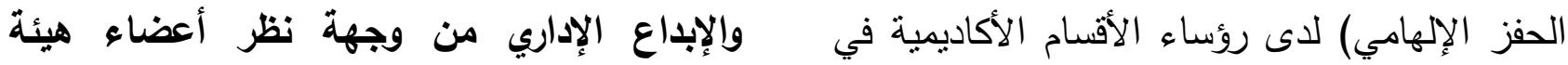
التريس في جامعة الإمام عبد الرحمن بن فيصل؟ جامعة الإمام عبد الرحمن بن فيصل. 
للإجابة عن هذا السؤال نم استخراج معامل الإبداع الإداري، والجدول (4) يوضح ذللك. ارتباط بيرسون بين أبعاد القيادة التحويلية وبين جدول (4) معامل ارتباط بيرسون للعلاقة بين أبعاد القيادة التحويلية وبين الإبداع الإداري

\begin{tabular}{|c|c|c|}
\hline \multicolumn{3}{|c|}{ الإبداع الإداري } \\
\hline **.799 & معامل الارتباط ر & \multirow[t]{3}{*}{ الكاريزما } \\
\hline .000 & الدلالة الإحصائية & \\
\hline 225 & العدد & \\
\hline **.809 & معامل الارتباط ر & \multirow{3}{*}{ تقدير الأفراد واحترامهح } \\
\hline .000 & الدلالة الإحصائية & \\
\hline 225 & العدد & \\
\hline$* * .833$ & معامل الارتباط ر & \multirow[t]{3}{*}{ لحافز الفكري } \\
\hline .000 & الدلالة الإحصائية & \\
\hline 225 & العدد & \\
\hline$* * .810$ & معامل الارتباطر & \multirow[t]{3}{*}{ الحفز الإلهامي } \\
\hline .000 & الدلالة الإحصائية & \\
\hline 225 & العدد & \\
\hline$* * .875$ & معامل الارتباط ر & \multirow[t]{3}{*}{ لقيادة التحويلية ككل } \\
\hline .000 & الدلالة الإحصائية & \\
\hline 225 & العدد & \\
\hline
\end{tabular}

الرحمن بن فيصل تعزى لمتغيرات (الجنس، المؤهل

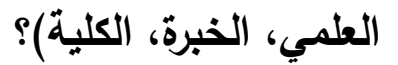
للإجابة عن هذا السؤال نم استخراج المتوسطات الحبره

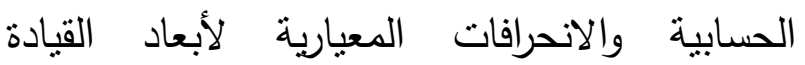
التحويلية، والإبداع الإداري من وجهة نظر أعضاء هيئة التدريس في جامعة الإمام عبد الرحمن بن فيصل حسب متغيرات (الجنس، والمؤهل العلمي، والخبرة، والكلية)، ولبيان الفروق الإحصائية بين

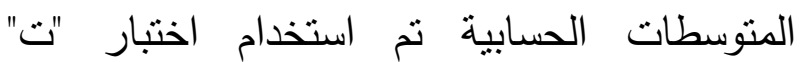

* * دالة إحصائيا عند مستوى الدلالة (0.05). *." *دالة إحصائيًا عند مستوى الدلالة (0.01).

يتبين من الجدول (ع) وجود علاقة إيجابية دالة إحصائيا بين مجالات (أبعاد)القيادة التحويلية وجئ التهادية والقيادة التحويلية ككل وبين الإبداع الإداري. عرض نتائج السؤال الثاني: هل توجد فروق ذإلداع الداتين دلالة إحصائية عند مستوى الدلالة (a) المتوسطات الحسابية لأبعاد القيادة التحويلية (الكاريزما، تقدير الأفراد واحترامهم، الحافز الفكري،

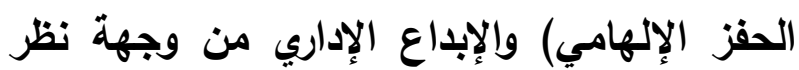
أعضاء هيئة التدريس في جامعة الإمام عبد الإبداع هند 
لمتغيرات الجنس، والمؤهل العلمي، والكلية، وتحليل توضح ذللك.

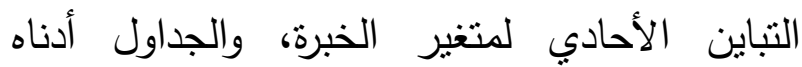

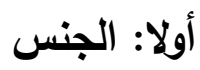

جدول (5) المتوسطات الحسابية والانحرافات المعيارية واختبار "ت" لأثر الجنس على أبعاد القيادة التحويلية والإبداع الإداري

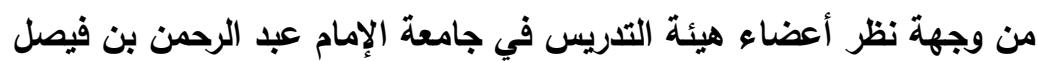

\begin{tabular}{|c|c|c|c|c|c|c|c|}
\hline الإحصائية & الحرية & "تيمة & الانحراف & الحسابي & العدد & & \\
\hline \multirow[t]{2}{*}{. 097} & \multirow[t]{2}{*}{223} & -1.665 & .460 & 3.34 & 84 & ذكر & \multirow[t]{2}{*}{ الكاريزما } \\
\hline & & -1.742 & .550 & 3.45 & 141 & أننى & \\
\hline \multirow[t]{2}{*}{.459 } & \multirow[t]{2}{*}{223} & -.742 & .521 & 3.34 & 84 & ذكر & \multirow{2}{*}{ تقدير الأفراد } \\
\hline & & -.747 & .534 & 3.39 & 141 & أنثى & \\
\hline \multirow[t]{2}{*}{290} & \multirow[t]{2}{*}{223} & -1.061 & .473 & 3.29 & 84 & ذكر & \multirow[t]{2}{*}{ الحافز الفكري } \\
\hline & & -1.090 & .527 & 3.37 & 141 & أنثى & \\
\hline \multirow[t]{2}{*}{.017} & \multirow[t]{2}{*}{223} & -2.413 & .478 & 3.27 & 84 & ذكر & \multirow[t]{2}{*}{ الحفز الإلهامي } \\
\hline & & -2.412 & .477 & 3.43 & 141 & أنثىى & \\
\hline \multirow[t]{2}{*}{.115} & \multirow[t]{2}{*}{223} & -1.582 & .436 & 3.31 & 84 & ذكر & \multirow[t]{2}{*}{ أبعاد القيادة التحويلية } \\
\hline & & -1.631 & .491 & 3.41 & 141 & أنثى & \\
\hline \multirow[t]{2}{*}{.464} & \multirow[t]{2}{*}{223} & -.734 & .458 & 3.34 & 84 & ذكر & \multirow[t]{2}{*}{ الإبداع الإداري } \\
\hline & & -.738 & 469 & 3.39 & 141 & أنثى & \\
\hline
\end{tabular}

ينبين من الجدول (5) عدم وجود فروق ذات دلالة كل كل وفي الإبداع الإداري باستثناء مجال الحفز

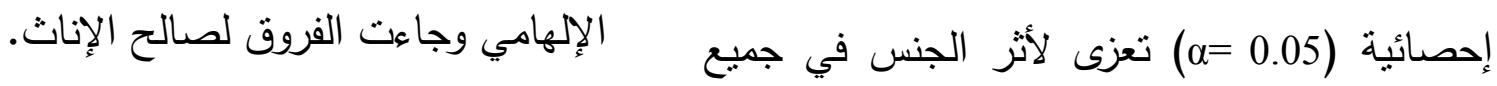
مجالات القيادة التحويلية وفي أبعاد القيادة التحويلية 
ثانياً: المؤهل العلمي

جدول (6) المتوسطات الحسابية والانحراقات المعيارية وإختبار "ت" لأثر المؤهل العلمي على أبعاد القيادة التحويلية والإبداع

الإداري من وجهة نظر أعضاء هيئة التدريس في جامعة الإمام عبد الرحمن بن فيصل

\begin{tabular}{|c|c|c|c|c|c|c|c|}
\hline الإحصائية & لدرجات & "تيمة & الانعراف & الحستبي & 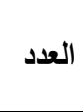 & العؤهل & \\
\hline \multirow[t]{2}{*}{.183} & \multirow[t]{2}{*}{223} & 1.335 & .477 & 3.48 & 69 & ماجسنتير & \multirow[t]{2}{*}{ الكاريزما } \\
\hline & & 1.397 & .537 & 3.38 & 156 & دكتوراه & \\
\hline \multirow[t]{2}{*}{.312} & \multirow[t]{2}{*}{223} & 1.012 & .490 & 3.42 & 69 & ماجسنير & \multirow[t]{2}{*}{ تقدير الأفراد واحترامهم } \\
\hline & & 1.055 & .545 & 3.35 & 156 & دكتوراه & \\
\hline \multirow[t]{2}{*}{.291} & \multirow[t]{2}{*}{223} & 1.058 & .439 & 3.39 & 69 & ماجستير & \multirow[t]{2}{*}{ الحافز الفكري } \\
\hline & & 1.142 & .535 & 3.32 & 156 & دكتوراه & \\
\hline \multirow[t]{2}{*}{.015} & \multirow[t]{2}{*}{223} & 2.443 & .407 & 3.49 & 69 & ماجستير & \multirow[t]{2}{*}{ الحفز الإلهامي } \\
\hline & & 2.653 & .505 & 3.32 & 156 & دكتوراه & \\
\hline \multirow[t]{2}{*}{.119} & \multirow[t]{2}{*}{223} & 1.564 & .415 & 3.45 & 69 & ماجسنتر & \multirow[t]{2}{*}{ أبعاد القيادة التحويلية ككل } \\
\hline & & 1.674 & .494 & 3.34 & 156 & دكتوراه & \\
\hline \multirow[t]{2}{*}{.496} & \multirow[t]{2}{*}{223} & .682 & .383 & 3.40 & 69 & ماجستير & \multirow[t]{2}{*}{ الإبداع الإداري } \\
\hline & & .753 & .496 & 3.36 & 156 & دكتوراه & \\
\hline
\end{tabular}

التحويلية ككل، وفي الإبداع الإداري باسنثناء مجال

يتبين من الجدول (6) عدم وجود فروق ذات دلالة

إحصائية (ب=0.05) تعزى لأثز المؤهل العلمي في الحفز الإلهامي وجاءت الفروق لصالح الماجستير . جميع مجالات القيادة التحويلية، وفي أبعائز أبعاد القيادة

ثالثاً: الخبرة

جدول (7): المتوسطات الحسابية والانحرافات المعيارية لأبعاد القيادة التحويلية والإبداع الإداري من وجهة نظر أعضاء هيئة التدريس في جامعة الإمام عبد الرحمن بن فيصل حسب متغير الخبرة

\begin{tabular}{|c|c|c|c|c|}
\hline الانحراف المعياري & المتوسط الحسابي & العدد - الع & الفئات & \\
\hline .598 & 3.37 & 68 & أقل من 5 سنوات & \multirow[t]{5}{*}{ الكاريزما } \\
\hline .433 & 3.51 & 79 & من 5 إلى 10 سنوات & \\
\hline .312 & 3.43 & 36 & من 10 إلى 15 سنة & \\
\hline .645 & 3.27 & 42 & 15 أكثر & \\
\hline .520 & 3.41 & 225 & المجموع & \\
\hline .577 & 3.31 & 68 & أقل من 5 سنوات & \multirow[t]{2}{*}{ تقدير الأفراد واحترامهم } \\
\hline .409 & 3.45 & 79 & من 5 إلى 10 سنوات & \\
\hline
\end{tabular}




\begin{tabular}{|c|c|c|c|c|}
\hline .321 & 3.43 & 36 & من 10 إلى 15 سنة & \\
\hline .735 & 3.26 & 42 & 15فأكثر & \\
\hline .528 & 3.37 & 225 & المجموع & \\
\hline .537 & 3.29 & 68 & أقل من 5 سنوات & \multirow[t]{5}{*}{ الحافز الفكري } \\
\hline .389 & 3.44 & 79 & من 5 إلى 10 سنوات & \\
\hline .311 & 3.38 & 36 & من 10 إلى 15 سنة & \\
\hline .721 & 3.21 & 42 & 15 1أكثر & \\
\hline .507 & 3.34 & 225 & المجموع & \\
\hline .545 & 3.34 & 68 & أقل من 5 سنوات & \multirow[t]{5}{*}{ الحفز الإلهامي } \\
\hline .395 & 3.48 & 79 & من 5 إلى 10 سنوات & \\
\hline .353 & 3.38 & 36 & من 10 إلى 15 سنة & \\
\hline .578 & 3.21 & 42 & 15 1أكثر & \\
\hline .483 & 3.37 & 225 & المجموع & \\
\hline .539 & 3.33 & 68 & أقل من 5 سنوات & \multirow{5}{*}{ ككل } \\
\hline .360 & 3.47 & 79 & من 5 إلى 10 سنوات & \\
\hline .285 & 3.41 & 36 & من 10 إلى 15 سنة & \\
\hline .623 & 3.24 & 42 & 15 1أكثر & \\
\hline .473 & 3.37 & 225 & المجموع & \\
\hline .489 & 3.33 & 68 & أقل من 5 سنوات & \multirow[t]{5}{*}{ الإبداع الإداري } \\
\hline .411 & 3.47 & 79 & من 5 إلى 10 سنوات & \\
\hline .254 & 3.41 & 36 & من 10 إلى 15 سنة & \\
\hline .604 & 3.22 & 42 & 15 فأكثر & \\
\hline .464 & 3.37 & 225 & المجموع & \\
\hline
\end{tabular}

يبـين الجـدول (7) تباينـاً ظاهريـاً في المتوسـطات فيصـل بسبب اختلاف فئات متغيـر الخبرة، ولبيـان الحســابية والانحرافـات المعياريــة لأبعـاد القيــادة دلالـة الفروق الإحصـائية بين المتوسطات الحسـابية التحويليـة والإبـداع الإداري مـن وجهة نظر أعضـاء تم اسـخدام تحليل التبـاين الأحسادي حسب الجدول هيئة التدريس في جامعسة الإمـام عبد الرحمن بـن (8). 
جدول (8) تحليل التباين الأحادي لأثر الخبرة على أبعاد القيادة التحويلية والإبداع الإداري من وجهة نظر أعضاء هيئة التدريس في جامعة الإمام عبد الرحمن بن فيصل الإلمال

\begin{tabular}{|c|c|c|c|c|c|c|}
\hline الإحصائية & قيمة ف & متوبط المربعات & درجات الحرية & مجموع المربعات & المصدر & \\
\hline .110 & 2.037 & $\begin{array}{l}.543 \\
.267\end{array}$ & $\begin{array}{c}3 \\
221 \\
224\end{array}$ & $\begin{array}{c}1.630 \\
58.976 \\
60.606\end{array}$ & داخل المجموعات المجمعات & الكاريزما \\
\hline .150 & 1.789 & $\begin{array}{l}.494 \\
.276\end{array}$ & $\begin{array}{c}3 \\
221 \\
224 \\
\end{array}$ & $\begin{array}{r}1.483 \\
61.080 \\
62.564\end{array}$ & داخل المجموعات المجموعات & تقدير الأفراد \\
\hline .071 & 2.378 & $\begin{array}{l}.601 \\
.253\end{array}$ & $\begin{array}{c}3 \\
221 \\
224\end{array}$ & $\begin{array}{c}1.803 \\
55.860 \\
57.663\end{array}$ & داخل المجموعات المجمعات & الحافز الفكري \\
\hline .030 & 3.042 & $\begin{array}{l}.690 \\
.227\end{array}$ & $\begin{array}{c}3 \\
221 \\
224\end{array}$ & $\begin{array}{r}2.070 \\
50.119 \\
52.189\end{array}$ & بين المجموعات & الحفز الإلهامي \\
\hline .054 & 2.585 & $\begin{array}{l}.566 \\
.219\end{array}$ & $\begin{array}{c}3 \\
221 \\
224\end{array}$ & $\begin{array}{c}1.698 \\
48.381 \\
50.079\end{array}$ & داخل المجموعات المجموعات & أبعاد القيادة \\
\hline .034 & 2.944 & $\begin{array}{l}.618 \\
.210\end{array}$ & $\begin{array}{c}3 \\
221 \\
224\end{array}$ & $\begin{array}{c}1.855 \\
46.422 \\
48.277\end{array}$ & داخل المجموعات المجموعات & الإبداع الإداري \\
\hline
\end{tabular}

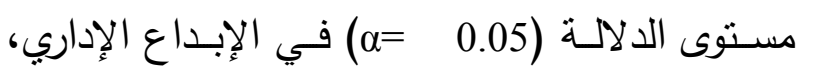

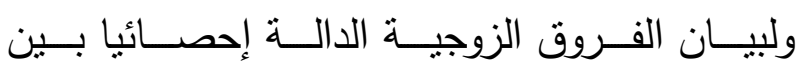
المتوسطات الحسـابية تم استخدام المقارنات البعديـة بطريقة شيفيه كما هو مبين في الجدول (9).
يتبين من الجدول (8) عدم وجود فروق ذات دلالة

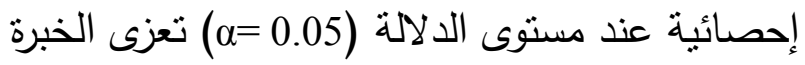
في جميع مجالات القيادة التحويلية والقيادة التحويلية ككل وفي الأداة ككل باستثناء مجال الحفز الإلهامي

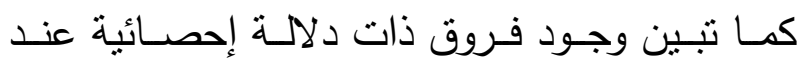


جدول (9) المقارنات البعدية بطريقة شيفيه لأثر الخبرة على بعد الحفز الإلهامي والإبداع الإداري

\begin{tabular}{|c|c|c|c|c|c|c|}
\hline 15 فأكثر & إلى 15 من 10 & 10 سنوات 5 إلى & سنوات 5 & الحستبي & الخبرة & \\
\hline & & & & 3.34 & أقل من 5 سنوات & \multirow{4}{*}{ الإلهامي } \\
\hline & & & .14 & 3.48 & من 5 إلى 10 سنوات & \\
\hline & & .09 & .04 & 3.38 & من 10 إلى 15 سنة & \\
\hline & .18 & $* .27$ & .13 & 3.21 & 15 فأكثر & \\
\hline & & & & 3.33 & أققل من 5 سنوات & \multirow{4}{*}{ الإباري } \\
\hline & & & .13 & 3.47 & من 5 إلى 10 سنوات & \\
\hline & & .06 & .07 & 3.41 & من 10 إلى 15 سنة & \\
\hline & .19 & $* 25$ & .11 & 3.22 & 15 فأكثر & \\
\hline
\end{tabular}

* دالة عند مستوى الدلالة (م=0.05).

يتبين من الجدول (9) وجود فروق ذات دلالة 10 سنوات) في الحفز الإلهامي وفي الإبداع

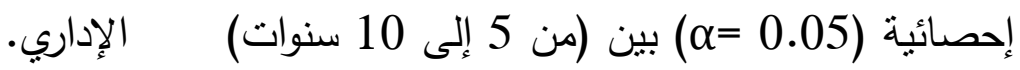
و(15 فأكثر) وجاءت الفروق لصالح (من 5 إلى رابعاً: الكية جدول (10) المتوسطات الحسابية والانحرافات المعيارية واختبار "ت" لأثر الكلية على أبعاد القيادة التحويلية والإبداع الإداري من وجهة نظر أعضاء هيئة التدريس في جامعة الإمام عبد الرحمن بن فيصل

\begin{tabular}{|c|c|c|c|c|c|c|c|}
\hline الإحصائية & لدرجات & "تيمة & الالمعياري & الحستوسي & العدد & & \\
\hline \multirow{2}{*}{.995} & \multirow{2}{*}{223} & \multirow{2}{*}{-.006} & .530 & 3.41 & 149 & إنسانية & \multirow{2}{*}{ الكاريزما } \\
\hline & & & .504 & 3.41 & 76 & علمبة & \\
\hline \multirow[t]{2}{*}{.274} & \multirow[t]{2}{*}{223} & \multirow[t]{2}{*}{-1.097} & .527 & 3.34 & 149 & إنسانية & \multirow[t]{2}{*}{ تقدير الأفراد واحترامهج } \\
\hline & & & .531 & 3.42 & 76 & علمية & \\
\hline \multirow[t]{2}{*}{.394} & \multirow[t]{2}{*}{223} & \multirow[t]{2}{*}{-.854} & .510 & 3.32 & 149 & إنسانبة & \multirow[t]{2}{*}{ الحافز الفكري } \\
\hline & & & .502 & 3.38 & 76 & علمبة & \\
\hline \multirow[t]{2}{*}{.914} & \multirow[t]{2}{*}{223} & \multirow[t]{2}{*}{-.108} & .482 & 3.37 & 149 & إنسانية & \multirow[t]{2}{*}{ الحفز الإلهامي } \\
\hline & & & .486 & 3.37 & 76 & علمبة & \\
\hline \multirow[t]{2}{*}{.590} & \multirow[t]{2}{*}{223} & \multirow[t]{2}{*}{-.539} & .477 & 3.36 & 149 & إنسانية & \multirow[t]{2}{*}{ أبعاد القيادة التحويلية } \\
\hline & & & .466 & 3.40 & 76 & علمية & \\
\hline \multirow[t]{2}{*}{.740} & \multirow[t]{2}{*}{223} & \multirow[t]{2}{*}{-.332} & .462 & 3.36 & 149 & إنسانية & \multirow[t]{2}{*}{ الإبداع الإداري } \\
\hline & & & .471 & 3.39 & 76 & علمية & \\
\hline
\end{tabular}

يتبين من الجدول (10) عدم وجود فروق ذات دلالة مناقشة النتائج والتوصيات إحصائية (م=0.05) تعزى لأثز الكلية في جميع أولا: مناقشة النتائج المتعلقة بالإجابة عن السؤال أبعاد القيادة التحويلية وفي أبعاد القيادة التحويلية الأول: هل توجد علاقة دالة إحصائيا عند مستوى الدلالة (م=0.05 ككل وفي الإبداع الإداري.

(الكاريزما، تقدير الأفراد واحترامهم، الحافز الفكري، 
يوفر إحساس جماعي مشترك بأولويات المهام، والأعمال المطلوبة الذي يؤدي إلى تحقيق إنتاجية تفوق ما هو متوقع. وأن رؤساء الأقسام يؤمنون بأهية الإبداع الإداري باعتباره بعدا تنافسيا يعمل

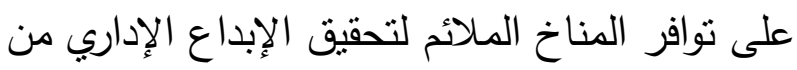
خلال النظر إلى الأثياء من زوايا مختلفة وتبني الإدائي أفكار وأساليب جديدة؛ لإثارة حماس أعضاء هيئة العاء التنريس لنقايم أراء جديدة ومبدعة، وإعطاء الأفكار المبتكرة كي تظهر نتائجها في فترة زمنية قصيرة، الفيداه والتتبؤ بمشكلات العمل قبل حدوثها، والابتعاد عن فئن فئن تقليد الآخرين في حل الشكلات التي تعترض سير العطل، ووضع الخطط الستنقلية، وتقديم التدريب الدطلوب للأعضاء ومساعدتهم بنظوير قدارتهم ومهاراتهم الإبداعية. وهذا يعمل على تحقيق الإبداع لإعاع الإداري بدرجة أكبر . ويمكن تفسير هذه النتائج في ضوء ما توصلت إليه بعض الدراسات السابقة فقد اتفقت هذه النتيجة مع ما فالئ Abbas et.al, وصلت إليه دراسة عباس وآخرون (2012) التي أثنارت إلى وجود تأثير إيجابي لأبعاد القيادة النحويلية (التأثير المثالي، ورعاية الأفراد التادير والاستثارة الفكرية والحفز الإلهامي)، وأن هناك ترابط التطاني بين أبعاد القيادة التحويلية وتعزيز سلوك العمل العان التهاك الإبداعي (بما في ذللك تعزيز الأفكار الإبداعية، وتوليد الفكرة، والالتزام بالعمل، وتتفيذ الفكرة الإنة الإبداعية). وتتقق هذه النتيجة ذاتها مع دراسة

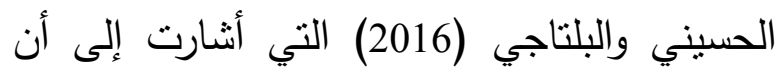

الحفز الإلهامي) والإبداع الإداري من وجهة نظر أعضاء هيئة التدريس في جامعة الإمام عبد الإل الرحمن بن فيصل؟ أظهرت النتائج المتعلقة بالإجابة عن هذا السؤال،

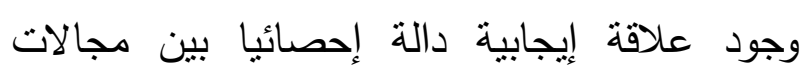
القيادة التحويلية (الكاريزما، تقدير الأفراد واحترامهر، الحافز الفكري، الحفز الإلهامي) والقيادة التحويلية ككل وبين الإبداع الإداري. وهذا يثير إلى النى أن النيان رؤساء الأقسام في جامعة الأمام عبد الرحمن بن الإدي فيصل يتمتعون بأبعاد القيادة التحويلية (الكاريزما،

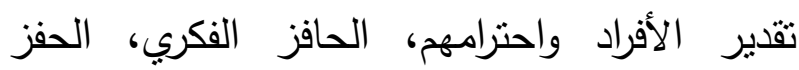
الإلهامي) من خلال الألتاد الك رؤساء الأفسام قيم وقناعات قوية، وروئة واضحة في تحقيق أهداف الجامعة، والتمتع بمهارات قيادية تعزز تقة الأعضاء بهم وتتجيعهم على تحقيق التميز في الأداء، التهاء والابتعاد عن مصالحهم الذاتية من أجل مصالح الأعضاء مما بوفر مناخا يثعر الأعضاء بالارتياح

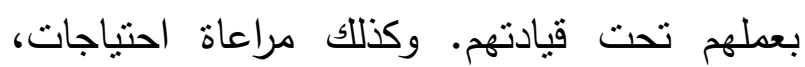
وقدرات، وطموحات أعضاء هيئة التنريس، والعمل على رفع الروح المعنوية وتفهم أحاسيسهم ومشاعرهم، والالتزام بمبدأ المساواة في تعاملهم، وتثقل أفكارهم وتشجيعهم على التعلم الذاتي المستمر .

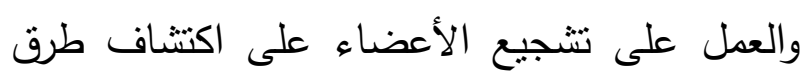
جديدة للتعامل مع المشكلات في مجال العمل وتقديم الاعناه أفكار إبداعية، والنظر إلى كيفية إتمام المهمات بأساليب إبداعية، والعمل بروح الفريق الواحد مما 
التحويلية، والإبداع الإداري. ومتغير الجنس هنا لا يعكس بالضرورة اختلافا بين أفراد الدراسة (إذا كانت

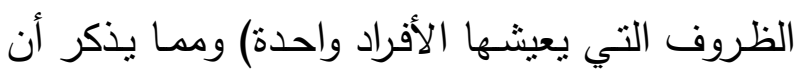
عدد الإناث في هذه الدراسة أكبر من عدد الذكور .

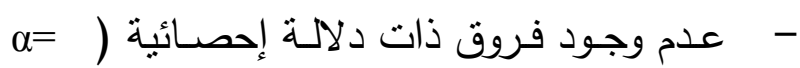
0.05) نعزى لأثز المؤهل العلمي: في جميع مجالات

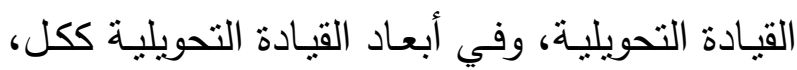

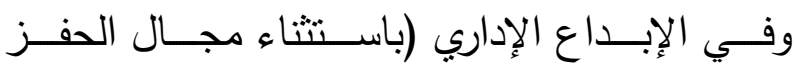

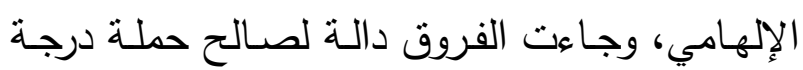

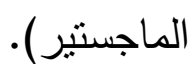
ويعزى ذلك إلى أن أعضاء الهيئة التدريسية (بدرجة

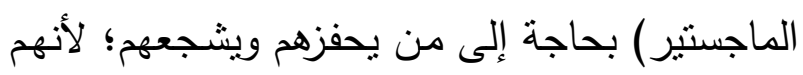

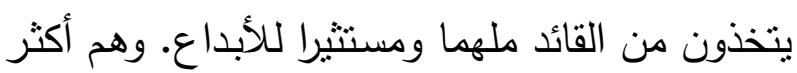
تأثرا مسن حملـة درجـة الدكتوراه (مـن أعضـاء هيئة التدريس). - وجود تباين ظـاهري في المتوسطات الحسابية

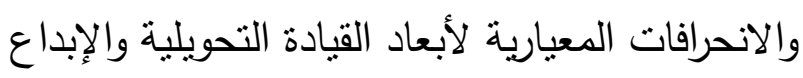
الإداري (من وجهة نظر أعضاء هيئة التدريس في لإسي

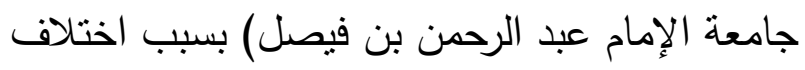
فئات متغير الخبرة. ولبيان دلالة الفروق الإحصائية بين المتوسطات الحسابية تم استخدام تحليل التباين

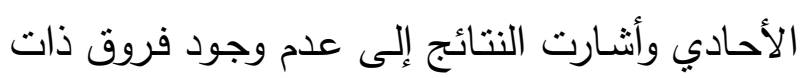

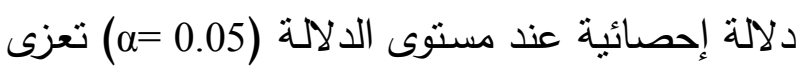
لمتغير الخبرة في: جميع مجالات القيادة التحويلية، والقيادة التحويليـة ككل، وفي الأداة ككل (باسـتنتاء مجال الحفز الإلهامي)، كما تبين وجود فروق ذات التهد
القيادة التحويلية تلعب دورا محوريا في: تعزيز

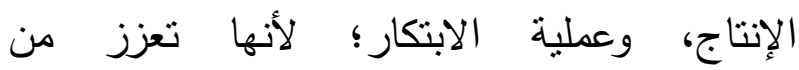
استراتيجيات تطوير الابتكار في التعليم. كما تتقق الابنى

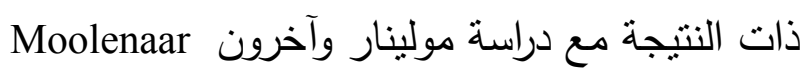
et.al,

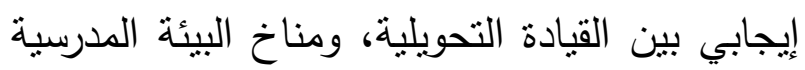
المبتكرة، وأن هناك استعداد لدى المعلمين للتغيير واكتساب المعارف الجديدة وممارسة الإبداع. ثانيا: مناقشة النتائج المتعلقة بالإجابة عن السؤال الثاني: هل توجد فروق ذات دلالة إحصائية عند

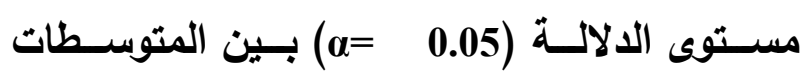

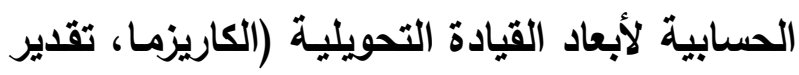
الأفراد واحترامهم، الحافز الفكري، الحفز الإلهامي) لإبعاد العادئ

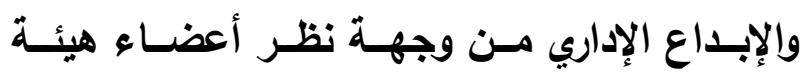

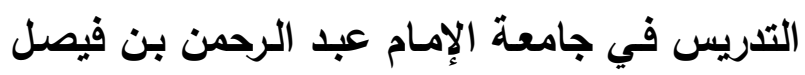
تعزى لمتغيرات (الجنس، المؤهل العلمـي، الخبرة،

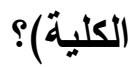
أثنارت نتائج هذا السؤال إلى:

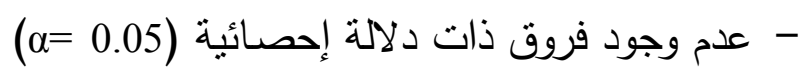

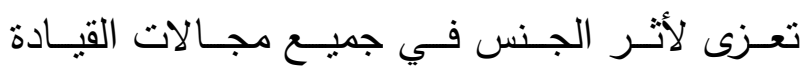

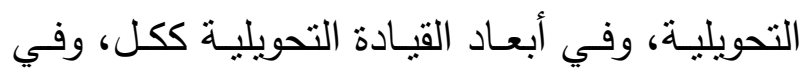
الإبــداع الإداري (باسـتنثاء مجـال الحفـز الإلهـامي وجاءت الفروق لصالح الإناث). وقد يعزى ذلك إلى أن الدرجات العلميـة والخبرات

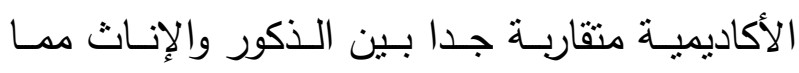
بـنعكس علـى وجـود علاقــة إيجابيـة بـين: القبــادة 
r. عقد الدورات التدريبية المتخصصة لرؤساء الأقسام، وتتجيعهم على تقديم أفكار جديدة لأساليب العمل وإنجاز

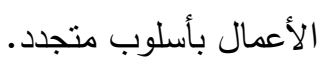
r. زيادة وتفعيل امتلاك رؤساء الأفسام في جامعة الإمام عبد الرحمن بن فيصل لمجالات القيادة التحويلية، والقدرات الإبداعية.

ع ـ ضرورة ربط منهجية القيادة التحويلية وعلاقتها بالإبداع الإداري في تحقق الانسجام مع الأهداف الاستراتيجية الموضوعة والمراد تحقيقها في الجامعة. ه. تتمية مهارات رؤساء الأقسام في الجامعة حتى يتم مساعدتهم في تكوين رؤية واضحة عن أفضل الممارسات

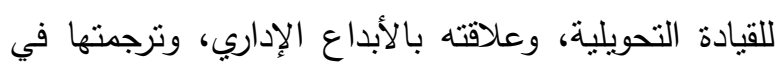
برامج تتفيذية عملية قابلة للنطبيق. 7. الاهتمام بأعضاء هيئة التدريس ممن ينوافر فيهر

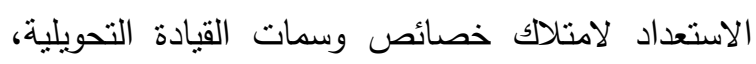

$$
\text { والمواهب والقدرات الإبداعية. }
$$

V. التأكيد على أجراء المزيد من الدراسـات العلميـة حول الإبداء

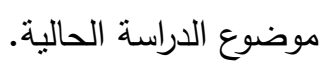

\section{المصادر والمراجع العربية رانه}

أبو النور، مروة. (2012). العوامل المؤيثرة في أنماط السلوك القيادي للد القيادات النسـائية في منظمات المجتمع المحلي. بحث لنيل درجة الدبلوم العالي في إدارة

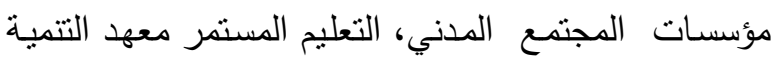
المجتمعية، الجامعة الإسلامية. الحسـيني، سوسـن، والبلتـاجي، إبـراهيم (2016). القيــادة

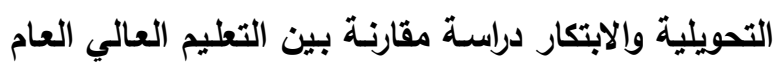

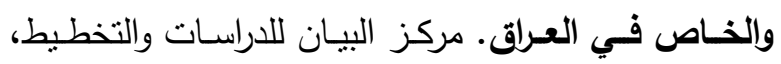

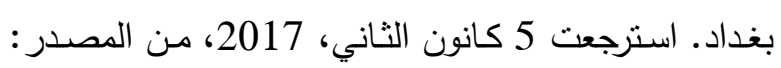
http://www.bayancenter.org/wpcontent/uploads
دلالة إحصـائية عند مستوى الدلالة (0.05 = $\alpha)$ في الإبــداع الإداري. ولبيــان الفـروق الزوجيــة الدالــة إحصـائيا بـين المتوسـطات الحسـابية، تم اسـتخدام المقارنات البعدية بطريقة شيفيه. وأشنارت النتائج إلى لي وجود فروق ذات دلالة إحصائية (1) (م) بين من (5 إلى 10 سنوات) و (15) فأكثر ، وجاءت الفروق لصالح من (5 إلى 10 سنوات) في الحفز الإلهامي، وفي الإبداع الإداري. وبعزى ذلك إلى مدى الـوعي الفكري عند أعضـاء هيئة التدريس الذين لديهم خبرة أكثر مما يدل على إلى أهميـة الخبـرة لأبعـاد القيـادة التحويليـة: (الكاريزمـا، تقـدير الأفـراد واحتـرامهم، الحـافز الفكـري، الحفـز الإلهامي) والإبداع الإداري.

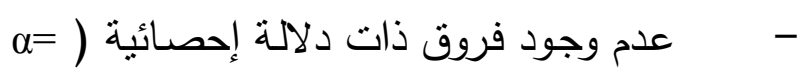
0.05) تعـزى لأثـر الكليـة في جميـع أبعـاد القيـادة

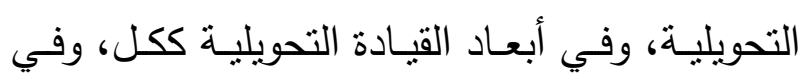
الإبداع الإداري.

ويعزى ذلك إلى أن الكليـات الإنسـانية والعلميـة في

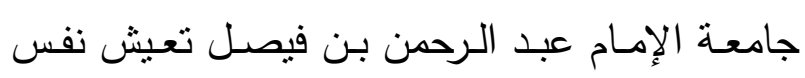
الظروف والإمكانيات مما يعني أنهم يتعرضون لنفس ظروف العمل (وبالتالي كانت النتيجة واحدة).

\section{توصيات الدراسة}

في ضوء نتائج الدراسة، فإن الباحثة نوصي بما يلي:

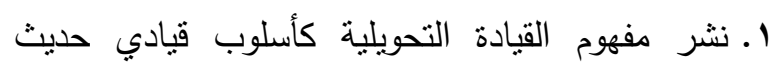
وفعال في الجامعات، وانعكاسها على الإبداع الإداري لأعضاء الهيئة التدريسية في ظل التطورات الحديثة. 
عباس، سـيلة. (2003). القيـادة الابتكاريـة والأداء المتميز: حقيبة تدريبية لتنمية الإبداع الإداري. عمان: دار الدارة

$$
\text { وائل للنشر والتوزيع. }
$$

القحطاني، سالم. (2003). القيادة الإدارية، التحول نحو ونول نموذج القيادة العالمي. الرياض: دار العلوم للطباعة والنشر.

قنديل، عـلاء. (2010). القبـادة الإداريـة وإدارة الابتكـار. عمان: دار الفكر .

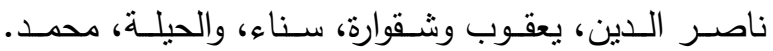
(2013). درجة تطبيق أبعاد القيادة التحويلية في الجامعات الأردنية الخاصة من وجهة نظر القادة الإداريين فيها. مجلة

$$
\text { الأداء الوظيفي. 2(1) ، 9-4. }
$$

هاوس، نورث. (2006). القيـادة الإداريـة النظريـة والتطبيق (صلاح المعيوف، مترجم). الرياض: معهد الإدارة

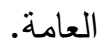

الهلالي، الشربيني. (2004). استخدام نظريتي القيادة التحويلية والإجرائية في بعض الكليات الجامعية. مجلة مستقبل التربية العربية، (21)، 134 - 139.

Abbas, G., Iqbal, J., Waheed, A., and Riaz, M. (2012). Relationship between Transformational Leadership Style and Innovative Work Behavior in Educational Institutions. Journal of Behavioral Sciences, 22 (3), 18-32.

Basham, L. (2010). Transformational or transactional leaders in higher education. International Review of Business Research Papers. International Review of Business Research Papers, 6 (6), 141152.

Bass, B. (1985). Leadership and Performance beyond Expectations. New York: The Free Press.

Bass, B. (2001). Leadership: Good, better, best. In: Bass, B. Leadership and performance beyond expectation. New York :The Free Press.

1. Kirkland, K. (2011). The effect of emotional intelligence on emotional competence and transformational leadership. $\mathrm{PhD}$ Thesis, University of New York, USA.
الخفاف، عبد المعطي. (2009). مبادئ الإدارة الحديثة، منهجية حديثة لتنمية الموارد البشرية. عمان: دار دجلة. الرقب، أحمد. (2010). علاقة القيادة التحويلية بتمكين العاملين في الجامعات القلسطينية بقطاع غزة. رسالة ماجستير غير منشورة، جامعة الأزهر ، مصر . شقوارة، سناء. (2012). درجة تطبيق القيادة التحويلية في جامعة الثرق الأوسط من وجهة نظر أعضاء الهيئتين التدريسية والإداريّة فيها. مجلة مركز تطوير الأداء الجامعي. (3)، 6 - 12 الصـيرفي، محمــــ (2003). الإدارة الرائســـة. عمــان: دار صفاء للنشر والتوزيع. العامري، احمد. (2002). السلوك القيادي التحويلي وسلوك المواطنة التتظيمية في الأجهزة الحكومية السعودية. المجلة العربيـة للعلوم الإداريـة لجامعة الكويت - إصدار مجلس الصس

$$
\text { النشر العلمي، } 9 \text { (1)، } 9 \text { - } 39 .
$$

العـازمي، محمـــ (2006). القيــادة التحويليـة وعلاقتهــا بالإبداع الإداري. رسالة ماجستير غير منشورة، جامعة نايف للعلوم الأمنية، المملكة العربية السعودية.

2. Mathew, V. (2010). Service Delivery Through Knowledge Management in Higher Education. Journal of Knowledge Management Practice, 11(3), $127-135$.

3. Moolenaar, N. M., Daly, A. J., and Sleegers, P. J. (2013). Occupying the principal position: Examining relationships between transformational leadership, social set work position, and schools' innovative climate. Educational Administration Quarterly, 46(5), 623-670.

4. Sergiovanni, T. (1996). Leadership for the schoolhouse: How is it different. why it is important. CA: Jossey-Bass, San Francisco.

5. Toremen, F. (2003). Creative school and administration. Educational Sciences: Theory and Practice, 3(1), 248-25.

6. Trafino, A. (2000). Transformational leadership: moving total quality management to world-class organizations. International Nursing Review. 47 (4), 232-242 


\title{
The relation between transformational leadership dimensions and administrative innovation from the point of view of faculty members at Imam Abdul Rahman bin Faisal University.
}

\author{
Yumna Ahmed Atoum \\ Assistant Professor university of Dammam, college of education in al-jubail
}

\begin{abstract}
This study aimed to identify the relation between transformational leadership dimensions and administrative innovation from the point of view of faculty members at Imam Abdul Rahman bin Faisal University. The study is important to reveal this relation to promote the practice of transformational leadership and its role in creating an appropriate environment for administrative innovation at universities. To achieve this objective a questionnaire was prepared for data collection and given to a random sample, (225) people, for the academic year 2017/2018. The results showed that:

- There is a statistically significant positive relation between the dimensions of leadership, and administrative innovation among heads of department.

- The absence of statistical differences $(\alpha=0.05)$ attributed to the impact of gender and scientific qualification in all aspects of transformational leadership except for the field of motivation in the gender variable in favor of females and M.A holders.

- The presence of statistical differences $(\alpha=0.05)$ for the variable experience and the differences came in favor of the years of experience between ( 5 to 10 years) in the motivation of inspiration and in the administrative innovation

The study recommended increasing awareness among HODS of the importance of adopting the method of transformational leadership as a modern and effective leadership method at universities and its reflection on the administrative innovation of faculty members by holding specialized training courses for HODS, encouraging them to present new ideas for work methods, and completing the work in through developing method.

Keywords: (administration innovation, transformational leadership).
\end{abstract}

